OPEN ACCESS

Edited by:

Enrique Cadenas,

University of Southern California,

United States

Reviewed by:

Patrizia Giannoni,

University of Nimes, France

Tracy D. Farr

The University of Nottingham,

United Kingdom

*Correspondence:

Jan Klohs

klohs@biomed.ee.ethz.ch

Received: 01 October 2018 Accepted: 30 January 2019

Published: 15 February 2019

Citation:

Ni R, Kindler DR, Waag $R$, Rouault $M$, Ravikumar P, Nitsch $R$, Rudin M, Camici GG, Liberale L,

Kulic L and Klohs J (2019) fMRI Reveals Mitigation of Cerebrovascular Dysfunction by Bradykinin Receptors 1 and 2 Inhibitor Noscapine in a Mouse Model of Cerebral Amyloidosis.

Front. Aging Neurosci. 11:27. doi: 10.3389/fnagi.2019.00027

\section{fMRI Reveals Mitigation of Cerebrovascular Dysfunction by Bradykinin Receptors 1 and 2 Inhibitor Noscapine in a Mouse Model of Cerebral Amyloidosis}

\author{
Ruiqing Ni1,2, Diana Rita Kindler', Rebecca Waag', Marie Rouault',2, \\ Priyanka Ravikumar ${ }^{3}$, Roger Nitsch ${ }^{3}$, Markus Rudin', Giovanni G. Camici', , \\ Luca Liberale ${ }^{3,5}$, Luka Kulic ${ }^{2,3}$ and Jan Klohs ${ }^{1,2 *}$
}

${ }^{1}$ Institute for Biomedical Engineering, University of Zurich and ETH Zurich, Zürich, Switzerland, ${ }^{2}$ Zurich Neuroscience Center,
Zürich, Switzerland, ${ }^{3}$ Institute for Regenerative Medicine, University of Zurich, Zürich, Switzerland, ${ }^{4}$ Center for Molecular
Cardiology, University of Zurich, Zürich, Switzerland, ${ }^{5}$ Department of Internal Medicine, University of Genoa, Genoa, Italy

Functional magnetic resonance imaging (fMRI) techniques can be used to assess cerebrovascular dysfunction in Alzheimer's disease, an important and early contributor to pathology. We hypothesized that bradykinin receptor inhibition alleviates the vascular dysfunction in a transgenic arcA $\beta$ mouse model of cerebral amyloidosis and that $\mathrm{fMRI}$ techniques can be used to monitor the treatment response. Transgenic $\operatorname{arc} A \beta$ mice, and non-transgenic littermates of 14 months-of-age were either treated with the bradykinin receptors 1 and 2 blocker noscapine or received normal drinking water as control over 3 months ( $n=8-11 /$ group) and all mice were assessed using fMRI at the end of the treatment period. Perfusion MRI using an arterial spin labeling technique showed regional hypoperfusion in arcA $\beta$ compared to non-transgenic controls, which was alleviated by noscapine treatment. Similarly, measuring cerebral blood volume changes upon pharmacological stimulation using vessel dilator acetazolamide revealed recovery of regional impairment of cerebral vascular reactivity in $\operatorname{arcA} \beta$ mice upon noscapine treatment. In addition, we assessed with immunohistochemistry betaamyloid $(A \beta)$ and inflammation levels in brain sections. Immunohistological stainings for $A \beta$ deposition (6E10) and related microgliosis (Iba1) in the cortex and hippocampus were found comparable between noscapine-treated and untreated $\operatorname{arc} A \beta$ mice. In addition, levels of soluble and insoluble $A \beta_{38}, A \beta_{40}, A \beta_{42}$ were found to be similar in brain tissue homogenates of noscapine-treated and untreated $\operatorname{arc} A \beta$ mice using electrochemiluminescent based immunoassay. In summary, bradykinin receptors blockade recovered cerebral vascular dysfunction in a mouse model of cerebral amyloidosis. $\mathrm{AMRI}$ methods revealed the functional deficit in disease condition and were useful tools to monitor the treatment response.

Keywords: Alzheimer's disease, beta-amyloid, bradykinin receptor, cerebral blood volume, cerebrovascular dysfunction, magnetic resonance imaging, perfusion imaging 


\section{INTRODUCTION}

Alzheimer's disease (AD) is the most common form of dementia and represents a complex and multi-factorial disorder. Hallmarks of the disease are the accumulation of abnormal beta-amyloid $(A \beta)$ and neurofibrillary tangles composed of hyperphosphorylated microtubule-associated tau protein, leading to neurodegeneration (Braak and Braak, 1991). Misfolded $A \beta$ and tau protein bind to receptors on microglia and astroglia, and trigger innate immune responses, which contribute to disease progression and severity (Heneka et al., 2015). In addition, alterations in the density and morphology of cerebral vasculature, a regional reduction of cerebral blood flow $(\mathrm{CBF})$ and an impaired cerebral vascular reactivity (CVR) have been reported in patients with $\mathrm{AD}$ and mild cognitive impairment (de la Torre, 2004; Kisler et al., 2017), and have been implicated to contribute to the cognitive impairment.

Several neuroimaging techniques have been developed to assess features of AD pathology in patients and animal models of the disease. The quest is to improve the diagnosis of the disease, to assess the disease stage, to select patients for treatment and to monitor the response to therapy. Among them, magnetic resonance imaging (MRI) has been used to detect degenerative changes in patients with AD (Frisoni et al., 2010). More recently, functional MRI (fMRI) techniques have been implemented to evaluate cerebrovascular abnormality in patients with $\mathrm{AD}$, which has been shown to occur early during the disease course (IturriaMedina et al., 2016). These comprise regional changes in CBF (Maier et al., 2014) and microvessel density (Klohs et al., 2012), disturbances of blood-brain barrier integrity (Montagne et al., 2017), impairment of vascular reactivity (Stoppe et al., 1995; Mueggler et al., 2002; Princz-Kranz et al., 2010; Dumas et al., 2012), and vascular remodeling (Dumas et al., 2012; Klohs et al., 2016).

The kallikrein-kinin system has been implicated as an important pathophysiological mediator of cerebral vascular dysfunction, neuroinflammation and $A \beta$ pathology in $\mathrm{AD}$ (Schmaier, 2016; Nokkari et al., 2018). Kinins, in particular bradykinin, are pro-inflammatory mediators with a range of physiological effects in the periphery, which have also been described in the central nervous system (Couture et al., 2000). Bradykinin, lysine-bradykinin, and bradykinin degradation products act through the activation of two $G$ protein-coupled bradykinin receptors (BRs): $\mathrm{B}_{1} \mathrm{R}$ and $\mathrm{B}_{2} \mathrm{R}$. Pharmacological antagonism or genetic deletion of $\mathrm{B}_{1} \mathrm{R}$ (Prediger et al., 2008; Lacoste et al., 2013; Passos et al., 2013; Asraf et al., 2016) and $\mathrm{B}_{2} \mathrm{R}$ (Bicca et al., 2015; Caetano et al., 2015) have been shown to alleviate the cognitive deficits in $\mathrm{A} \beta$-injected or transgenic $\mathrm{AD}$ animal models.

In the present study, we hypothesized that chronic oral treatment with the phthalideisoquinoline alkaloid noscapine, a $B_{1} R$ and $B_{2} R$ antagonist (Landen et al., 2004), ameliorates the $\mathrm{CBF}$ and $\mathrm{CVR}$ abnormalities in $\operatorname{arc} \mathrm{A} \beta$ mouse model of amyloidosis (Merlini et al., 2011). We investigated the effect of BR blockade by noscapine on CBF and CVR in $\operatorname{arcA} \beta$ mice using fMRI techniques. In addition, we studied the effects of noscapine treatment on $A \beta$ deposits and microglia by immunohistochemical and biochemical analysis.

\section{MATERIALS AND METHODS}

\section{Animals}

All experiments were performed in accordance with the Swiss Federal Act on Animal Protection and were approved by the Cantonal Veterinary Office Zurich (Permit Number: 90-2016). All procedures fulfilled the ARRIVE guidelines on reporting animal experiments. ArcA $\beta$ transgenic mice, with human APP695 transgene containing the Swedish (K670N/M671L) and Arctic (E693G) mutation under the control of the prion protein promoter (Knobloch et al., 2007), were used. Animals were kept in a temperature-controlled room in individually ventilated cages under $12 \mathrm{~h}$ light/dark cycle and access to pelleted food and water were provided ad libitum. Paper tissue was given as environmental enrichment. A sample size of $n=7$ per group was calculated for the primary end point $\mathrm{CBF}$, a fixed effect omnibus, one-way ANOVA with four groups, and an effect size $f=0.72$, $\alpha=0.05$ and $\beta=0.2$. Consequently, group sizes $n>7$ were used ( $G^{*}$ power, University of Düsseldorf, Germany).

\section{Measurement of Plasma Bradykinin Levels}

Six $\operatorname{arcA} \beta$ and seven non-transgenic littermates (NTLs) of 17 months-of-age were used. Blood from the vena cava of the mice was collected into Eppendorf tubes filled with $50 \mu \mathrm{l}$ $0.5 \mathrm{M}$ ethylenediaminetetraacetic acid (EDTA, Sigma-Aldrich $\mathrm{GmbH}$, Switzerland) and centrifuged at $4^{\circ} \mathrm{C}, 1000 \mathrm{~g}$ for $15 \mathrm{~min}$. The blood : EDTA volume ratio was approximately $8: 1$. The plasma supernatants were collected as $50 \mu \mathrm{l}$ aliquots, frozen and kept at $-80^{\circ} \mathrm{C}$, until use. The enzyme immunoassay (RayBiotech, Norcross, GA, United States) was used for bradykinin level measurement. A known concentration of biotinylated bradykinin was spiked into samples and standards, which were then added to wells. Here, biotinylated-bradykinin competes with the endogenous bradykinin in plasma for binding to the monoclonal anti-bradykinin antibody immobilized on the wall. After color development reaction, the intensity of the colorimetric signal was directly proportional to the amount of biotinylated bradykinin captured by the antibody, which inversely correlated to the amount of endogenous peptide in the sample or standard. A standard curve for the quantification of bradykinin concentration in the samples was generated. The lower detection limit of the assay was $1.4 \mathrm{ng} / \mathrm{ml}$ bradykinin.

\section{Study Design Noscapine Treatment}

A flowchart of the design for the noscapine treatment study is shown in Supplementary Figure 1. Twenty $\operatorname{arc} A \beta$ and 17 NTLs of both genders at approximately 14 months-of-age (at the start of the study) were used for the 3 months treatment study (Table 1). Animals of both genders were randomly allocated to experimental groups. Experimenters were blinded during data acquisition and analysis. Mice in the treatment arm were supplied 
TABLE 1 | Demographic information, weight, and blood pressure of mice.

\begin{tabular}{|c|c|c|c|c|}
\hline Group & NTL & NTL noscapine & $\operatorname{arcA} \beta$ & $\operatorname{arcA} \beta$ noscapine \\
\hline$N$ & 8 & 9 & 9 & 11 \\
\hline Female/male & $4 / 4$ & $7 / 2$ & $5 / 4$ & $4 / 7$ \\
\hline Age (months)* & $16.6 \pm 0.3$ & $16.8 \pm 0.4$ & $16.6 \pm 0.4$ & $16.6 \pm 0.4$ \\
\hline Weight before treatment (g) & $31.5 \pm 4.3$ & $28.1 \pm 3.8$ & $26.8 \pm 4.7$ & $29.1 \pm 3.1$ \\
\hline Weight end of treatment (g) & $32.5 \pm 4.6$ & $28.3 \pm 2.6$ & $28.1 \pm 4.4$ & $29.3 \pm 3.6$ \\
\hline Systolic blood pressure (bpm) & $86.3 \pm 24.8$ & $117.4 \pm 16.0$ & $107.8 \pm 36.4$ & $108.2 \pm 22.6$ \\
\hline Diastolic blood pressure (bpm) & $61.8 \pm 29.0$ & $76.2 \pm 11.9$ & $75.1 \pm 43.1$ & $76.7 \pm 24.7$ \\
\hline
\end{tabular}

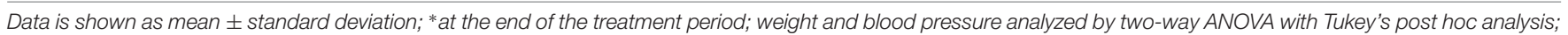
age analyzed by one-way ANOVA with Tukey's post hoc analysis, NTL, non-transgenic littermates.

with noscapine (Sigma-Aldrich $\mathrm{GmbH}$, Switzerland) in acidified drinking water for 3 months before the first measurement. Noscapine ( $3 \mathrm{~g} / \mathrm{l}$ ) was dissolved in double distilled water, adjusted to $\mathrm{pH} 3.5$ (Sigma-Aldrich $\mathrm{GmbH}$, Switzerland). Prior to the treatment study, high performance liquid chromatography was performed to measure the stability of noscapine in acidified double distilled water ( $\mathrm{pH} 3.5$ ), where 94 and $70 \%$ of noscapine were detectable after $24 \mathrm{~h}$ and 2 days, respectively. Therefore, we prepared fresh noscapine solution $(\mathrm{pH} 3.5)$ daily and protected it from light to ensure stability. For the control group, double distilled water was provided. All animals were weighed once per week during the study. Blood pressure of the mice were assessed non-invasively at the end of the treatment by tailcuff using CODA monitor (Kent Scientific, Corp., Torrington, CT, United States). Systolic and diastolic blood pressures of each mice were assessed consecutively twenty times, and were averaged (Table 1).

\section{Functional Magnetic Resonance Imaging}

All MRI scans were performed on a 7/16 small animal MR Pharmascan (Bruker Biospin GmbH, Ettlingen, Germany) equipped with an actively shielded gradient set of $760 \mathrm{mT} / \mathrm{m}$ with a $80 \mu$ s rise time and operated by a Paravision 6.0 software platform (Bruker Biospin $\mathrm{GmbH}$, Ettlingen, Germany). Mice were anesthetized with an initial dose of $4 \%$ isoflurane (Abbott, Cham, Switzerland) in oxygen/air (200/800 $\mu \mathrm{l} / \mathrm{min})$ mixture and anesthesia were maintained at $1.5 \%$ isoflurane in oxygen/air $(100 / 400 \mu \mathrm{l} / \mathrm{min})$ mixture. Mice were placed in prone position on a water-heated support to keep body temperature within $36.5 \pm 0.5^{\circ} \mathrm{C}$. Body temperature was monitored with a rectal temperature probe.

Perfusion MRI was performed using an arterial spin labeling technique as described previously (Ni et al., 2018a). The Paxinos mouse brain atlas was used as anatomical reference for scan positioning and analysis (Paxinos and Franklin, 2012). Reassessment of CBF (test-retest analysis) was performed in 17 mice randomly selected from the groups for assuring the repeatability of the CBF measurement $(n=17)$.

Cerebral vascular reactivity was assessed, after a 1 week of recovery following perfusion $\mathrm{MRI}$, by measuring cerebral blood volume (CBV) changes upon pharmacological stimulation using vessel dilator acetazolamide, as previously reported (Mueggler et al., 2002; Princz-Kranz et al., 2010). The scanner was equipped with a $300 \mathrm{MHz}$ cryogenic radiofrequency probe for conducting the CVR assay. Mice were endotracheallyintubated and maintained at $1.5 \%$ isoflurane in oxygen/air (100:400 $\mu \mathrm{l} / \mathrm{min})$ mixture and actively ventilated at a rate of 90 breaths/minute and a tidal volume of approximately $0.3 \mu \mathrm{l} /$ breath using a small animal ventilator (MRI-1, CWE, Inc., United States). Animal's tail veins were cannulated for administration of drugs and contrast agent. A neuromuscular blocking agent gallanmine triethiode (Sigma-Aldrich $\mathrm{GmbH}$, Switzerland) was administered twice as a bolus ( $40 \mu \mathrm{l}, 7 \mathrm{mg} / \mathrm{ml})$ at the beginning and before i.v. injection of contrast agent while the isoflurane level was reduced to $1.2 \%$. $\mathrm{T}_{2}$-weighted anatomical reference images were acquired using a spin echo rapid acquisition with relaxation enhancement (RARE) sequence with the same anatomical geometry as RARE sequence at pre- and post-injection of vessel dilator acetazolamide. Fifteen minutes after injection of contrast agent, of gallanmine was injected i.v. (21 mg/kg body weight). Then, eight sequential pre-contrast agent scans at baseline signal intensity $S_{\text {pre }}\left(\mathrm{CBV}_{0}\right.$ image) were acquired using a RARE sequence: temporal resolution $=40 \mathrm{~s}$, repetition time $=3333 \mathrm{~ms}$, echo time eff $=81 \mathrm{~ms}$, RARE factor $=32$, field-of-view $=20 \mathrm{~mm} \times 20 \mathrm{~mm}$, imaging matrix $=133 \times 103$, slice thickness $=1 \mathrm{~mm}, 1.5 \mathrm{~mm}$ gap, resolution $=150 \mu \mathrm{m} \times 200 \mu \mathrm{m}$. FLASH sequence $\mathrm{NR}=50$ was used for ensuring the successful injection of the contrast agent. After 10 repetitions, iron oxide contrast agent Endorem (50 mg Fe/kg body weight, Guerbet SA, Roissy-en-France, France) was administered i.v. A RARE sequence was started after 5 min after repetition $=100$ and 8 averages, when the contrast agent concentration had reached steady state. After the $30^{\text {th }}$ repetition $(20 \mathrm{~min})$, acetazolamide $(30 \mathrm{mg} / \mathrm{kg}$ body weight; Diamox ${ }^{\circledR}$ parenteral, Goldshield Pharmaceuticals, Ltd., Croydon, United Kingdom) was administered i.v. as a bolus. Additional 70 images were collected $(46.7 \mathrm{~min})$, yielding the image series $S_{(t)}$.

\section{Brain Tissue Collection}

After MRI, mice were anesthetized under ketamine/xylazine/acepromazine maleate $(75 / 10 / 2 \quad \mathrm{mg} / \mathrm{kg}$ body weight, bolus injection, i.p.). Mice were perfused using cold PBS ( $\mathrm{pH}$ 7.4). Brains were removed from the skull. The left brain hemispheres were fixed in $4 \%$ paraformaldehyde (Sigma-Aldrich, Switzerland) in PBS ( $\mathrm{pH} 7.4$ ) at $4^{\circ} \mathrm{C}$ and embedded in paraffin 
following routine procedures. The right hemispheres were snap frozen and stored at $-80^{\circ} \mathrm{C}$, until use.

\section{Meso Scale Discovery (MSD) Analysis}

Meso Scale Discovery (MSD) analysis was performed as described previously (Kulic et al., 2012) in NTL $(n=6)$, NTL noscapine $(n=8), \operatorname{arc} \mathrm{A} \beta(n=7)$, and $\operatorname{arcA} \beta$ noscapine $(n=4)$ mice. In brief, frozen brain tissues were homogenized using a glass Teflon homogenizer with homogenization buffer containing $100 \mathrm{mM}$ Tris- $\mathrm{HCl}, 150 \mathrm{mM} \mathrm{NaCl}$ and complete EDTA-free protease inhibitor cocktail (Roche Diagnostic, Risch-Rotkreuz, Switzerland). The amount of buffer used was equivalent to 10fold wet weight of the brain tissue. The brain homogenates were centrifuged at 100,000 $\mathrm{g}$ for $1 \mathrm{~h}$ and supernatants were collected Tris-buffered saline (TBS) fraction and pellets were homogenized again in homogenization buffer containing $2 \%$ of sodium dodecyl sulfate (SDS). Centrifugation was repeated and the supernatants (SDS-fraction) were again collected. The remaining pellet was suspended in $70 \%$ formic acid (FA), sonicated four times for $30 \mathrm{~s}$ at $30 \%$ power and again centrifuge at $100,000 \mathrm{~g}$ for $30 \mathrm{~min}$. The supernatants were collected (FA-fraction), lyophilized and reconstituted in homogenization buffer. $A \beta_{38}, A \beta_{40}$, and $A \beta_{42}$ levels were measured in the abovementioned brain homogenate fractions using an MSD 3plex multi-SPOT A $\beta$ human kit (Gaithersburg, MD, United States). Plates were measured on an MSD SECTOR Imager 600 plate reader (Gaithersburg, MD, United States). The MSD DISCOVERY WORKBENCH software (Version 3.0.18) (Gaithersburg, MD, United States) with Data Analysis Toolbox was used to calculate sample concentrations by comparing them against a standard curve.

\section{Immunohistochemistry}

Cy3-6E10 (mouse anti-A $\beta$-SIG-39320, Signet Laboratories, United States, 1:5000 dilution) and Alexa488-ionized calciumbinding adapter molecule (Iba1, Rabbit anti-Iba1, Wako Chemicals, United States, HRP Rabbit AK, 1:2500 dilution) immunostainings were done on $5 \mu \mathrm{m}$ brain sections as previously described (Spani et al., 2015). Nuclei were counterstained by DAPI, while adjacent sections were stained with hematoxylin and eosin. Images were examined using Leica DM 4000B microscopy with Olympus DP71 digital camera and VIS (Visiopharm Integrator System) version 4.4.6.9 software at $5 \times, 10 \times, 20 \times$, and $40 \times$ magnification. Images were captured on each slices at ( $\times 5,10,20,40$ magnification). Quantification of the images was performed blinded using Image J (NIH, United States). For quantitative image analysis, the cortex and hippocampus were analyzed on three equidistant sagittal hemibrain sections of each mouse (interaural lateral 0.60 to $0.72 \mathrm{~mm}$ ) at $10 \times$, three images taken at each region on one slice. Images of the cortex and hippocampus were taken with an exposure time of $200 \mathrm{~ms}$ (amyloid, 6E10-Cy3), $308 \mathrm{~ms}$ (microglia, Iba1-Alexa488), $30 \mathrm{~ms}$ (nucleus, DAPI) of the same areas. The Paxinos mouse brain atlas was used as anatomical reference (Paxinos and Franklin, 2012). Threshold and particle analysis functions were applied, resulting in $\mathrm{A} \beta$ and microglia covered area in percentage.

\section{Data Analysis}

Two persons performed data analysis independently, and the obtained results were averaged. CBF maps from arterial spin labeling data was computed as previously described (Ni et al., 2018a). Region of interest (ROIs) were evaluated in the cerebral cortex, hippocampus and thalamus using AFNI (NIH, United States) with $\mathrm{T}_{2}$-weighted anatomical scan and the Paxino mouse brain atlas as reference (Paxinos and Franklin, 2012). Figure 2A shows the placement of the ROIs on the anatomical scans, which were transferred to the CBF map. CBF in ROIs was calculated from both $\mathrm{T}_{1}$ values (Zerbi et al., 2014) using MATLAB R2015b (The Mathworks, Natick, MA, United States):

$$
C B F / \lambda=\frac{T_{1 \text { global }}}{T_{1 \text { blood }}}\left(\frac{1}{T_{1 \text { selective }}}-\frac{1}{T_{1 \text { global }}}\right)
$$

where $\lambda$ is the blood/tissue partition coefficient for water, assumed to be $0.9 \mu \mathrm{l} / \mathrm{g}$ (Leithner et al., 2008) and $\mathrm{T}_{1}$ blood was assumed to be $2.007 \mathrm{~s}$ at $7 \mathrm{~T}$ (Zhang et al., 2013).

Assessment of CVR was performed using Biomap 6 (Novartis Institute for Biomedical Research, Basel, Switzerland). The ROIs were defined in six brain regions (motor cortex, sensory cortex, striatum, hippocampus, thalamus, and cerebellum). Baseline $\mathrm{CBV}\left(\mathrm{CBV}_{0}\right)$ was calculated for each ROI. The baseline CBV and relative percentage changes of $\mathrm{CBV}$ versus baseline $\mathrm{CBV}$ $(\triangle \mathrm{CBV}(t))$ were computed on a pixel-by-pixel basis according to:

$$
\begin{gathered}
\triangle C B V \%(t)=\frac{\Delta C B V(t)}{C B V_{0}} \times 100=\frac{\ln (S(t)) / \ln \left(S_{0}\right)}{\ln \left(S_{0}\right) / \ln \left(S_{\text {pre }}\right)} \times 100 \\
C B V_{0}=-\ln \left(\frac{T}{T_{0}}\right)=-\ln \left(\frac{\text { mean Post } C A}{\text { mean Pre } C A}\right) \\
\operatorname{sqrt}(\Delta C B V \%(t))=a \times \text { time }+b
\end{gathered}
$$

Linear regression analysis was performed on the square root of the $\triangle C B V \%(t), \operatorname{sqrt}(\triangle \mathrm{CBV} \%(\mathrm{t}))$ with time. ROIs of specific brain regions in the left and right hemispheres were merged into one ROI. Figure 3A shows the placement of the ROIs for analyzing the CBV data using $\mathrm{T}_{2}$-weighted anatomical scan and the Paxino mouse brain atlas as reference (Paxinos and Franklin, 2012). The response time curve $\triangle \mathrm{CBV}(t)$ and the late $\Delta \mathrm{CBV}(\%)$ of slices 90-100 (40-46.7 $\mathrm{min}$ ) were compared between groups.

\section{Statistical Analysis}

For comparison of the continuous numeric data such as weight, blood pressure before and after treatment, a two-way ANOVA with Tukey's post hoc analysis (GraphPad Prism 6.0, San Diego, CA, United States) was used. For comparison of age between groups, a one-way ANOVA with Tukey's post hoc analysis was used. For comparison of bradykinin plasma level between NTLs and $\operatorname{arcA} \beta$ mice, unpaired $t$-test was used after ShapiroWilk normality test. For group comparison of $\mathrm{CBF}, \mathrm{CBV}_{0}$, late $\triangle \mathrm{CBV}(\%)$, slope of $\operatorname{sqrt}(\triangle \mathrm{CBV} \%(\mathrm{t}))$ and immunostaining of $\mathrm{A} \beta$ and Iba1 in multiple brain regions, two-way ANOVA with Turkey's post hoc analysis were used. For MSD measurement of $\mathrm{A} \beta$ level in different brain fractions of test-retest analysis of the 
CBF data of the same mice, a Pearson correlation analysis was performed. All data are present as mean \pm standard deviation. Significance was set at ${ }^{*} p<0.05,{ }^{* *} p<0.01,{ }^{* * *} p<0.001$.

\section{RESULTS}

\section{Demographics and Blood Pressure}

Demographic information, body weight before/after the treatment and blood pressure are summarized in Table 1 including NTL $(n=8)$, NTL noscapine $(n=9)$, $\operatorname{arcA} \beta(n=9)$, and $\operatorname{arcA} \beta$ noscapine $(n=11)$. One-way ANOVA showed that groups did not differ in terms of age among the groups (approximately 16.6 months-old after the treatment), F(DFn, DFd): $F(3,33)=0.4467, p=0.7212$. And no differences between body weights before and after the treatment period were found between groups $F(3,66)=0.104, p=0.9574$. As inhibitors of BRs can affect the angiotensin system (AbdAlla et al., 2001; Jing et al., 2012), we measured the systolic and diastolic blood pressure in mice at the end of the treatment period. Blood pressure was not statistically different between noscapine-treated NTLs, and $\operatorname{arcA} \beta$ mice compared to untreated groups $F(3,33)=0.1594$, $p=0.9229$ (Table 1$)$.

\section{Increased Plasma Levels of Bradykinin 1-5 in $\operatorname{arcA} \beta$ Mice}

We tested with enzyme immunoassay if kallikrein-kinin system is activated in the arcA $\beta$ mouse model of amyloidosis. We detected that $\operatorname{arc} \mathrm{A} \beta$ mice have higher levels of circulating bradykinin in the plasma, as compared to NTLs $(33.2 \pm 10.5$ vs. $20.3 \pm 7.43 \mathrm{ng} / \mathrm{ml}$, $p=0.0338$, Shapiro-Wilk $p=0.2514$ and $p=0.3587$ respectively, passing normality test) (Figure 1).

\section{Noscapine Treatment Ameliorated Regional Hypoperfusion}

We first tested the effect of chronic oral noscapine treatment on cerebral perfusion of $\operatorname{arc} A \beta$ mice. Figure $\mathbf{2 A}$ shows the

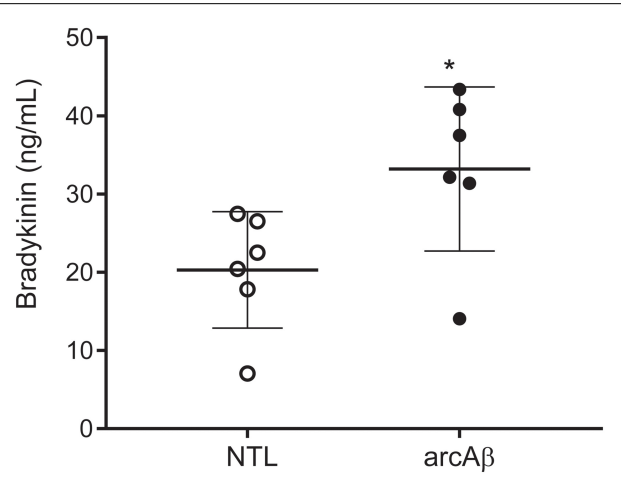

FIGURE 1 | Bradykinin levels in the plasma of arcA $\beta$ mice and non-transgenic littermates (NTLs) measured by using enzyme immunoassay. ArcA $\beta$ mice $(n=6)$ have higher levels of circulating bradykinin, as compared to NTL $(n=6) ;{ }^{*} p<0.05$, unpaired Student's $t$-test; Shapiro-Wilk $p=0.2514$ and $p=0.3587$, respectively passing normality test. placement of acquisition slice and ROIs of CBF analysis on the structural MRI image. Figure 2B shows representative coronal CBF maps for all four groups of mice. Regional analysis of the perfusion MRI data showed the interaction between brain region and treatment $\times$ genotype with $\mathrm{F}(\mathrm{DFn}, \mathrm{DFd})$ : $F(6,186)=2.316, p=0.0351$; reduced $\mathrm{CBF}$ in the cortex $(123.0 \pm 40.8$ vs. $165.4 \pm 31.1 \mu \mathrm{l} / 100 \mathrm{~g} / \mathrm{min}, p=0.0192)$ and thalamus $(154.1 \pm 61.1$ vs. $200.5 \pm 38.4 \mu \mathrm{l} / 100 \mathrm{~g} / \mathrm{min}, p=0.0065)$ in untreated $\operatorname{arcA} \beta$ mice compared to untreated NTLs were observed (Figure 2C). Noscapine-treated $\operatorname{arcA} \beta$ mice showed significantly higher $\mathrm{CBF}$ values in the cortex (167.6 \pm 33.9 vs. $123.0 \pm 40.8 \mu \mathrm{l} / 100 \mathrm{~g} / \mathrm{min}, p=0.0023)$ and thalamus $(196.3 \pm 43.8$ vs. $154.1 \pm 61.1 \mu \mathrm{l} / 100 \mathrm{~g} / \mathrm{min}, p=0.0043)$ compared to untreated $\operatorname{arcA} \beta$ mice. The test-retest results of two perfusion MRI measurements in the same mice are shown in Supplementary Figure 2. Pearson correlation analysis showed a robust correlation $(r=0.9491, p<0.0001, n=17)$ between test and re-test measures. Taken together, perfusion imaging revealed that noscapine treatment mitigated the hypoperfusion seen in $\operatorname{arcA} \beta$ mice of this age.

\section{Noscapine Treatment Mitigated Impaired CVR}

We then tested the effect of noscapine treatment on the CVR by measuring CBV after stimulation with vessel dilator acetazolamide. One mouse in the un-treated NTLs, noscapinetreated NTLs and noscapine-treated $\operatorname{arcA} \beta$ group showed negative $\triangle \mathrm{CBV}$ and were categorized as outliers and thus excluded from further analysis. Figure 3A illustrated the ROIs drawing on four different levels of MR slices identified using the Paxinos mouse brain atlas for CBV analysis (Paxinos and Franklin, 2012). Figure 3B illustrated the representative $\triangle \mathrm{CBV}$ of different anatomical levels of mice at $46 \mathrm{~min}$ after-the injection of acetazolamide $(t=0 \mathrm{~min})$ overlaid with corresponding $\mathrm{T}_{2}$-weighted $\mathrm{MRI}$. No difference was observed in baseline $\mathrm{CBV}_{0}$ values among groups [two-way ANOVA with Tukey's post hoc analysis, $F(15,186)=0.1919$, Supplementary Figure 3].

In Figure 4 the change in $\triangle \mathrm{CBV}$ is plotted as a function of time for the four groups of mice $(t=-20 \mathrm{~min}$ : contrast agent injection; $t=0 \mathrm{~min}$ : acetazolamide stimulus). Linear regression analysis were performed on sqrt (\% $\triangle \mathrm{CBV})$ with time (0-46.7 min). Two way ANOVA with Tukey's post hoc analysis showed significant interaction $F(15,222)=11.92$, $p<0.0001$. The slope and intercept and goodness of the fitting are summarized in Table 2. A flatter slope of $\operatorname{sqrt}(\% \Delta \mathrm{CBV}(\mathrm{t}))$ was observed in the motor cortex $(p<0.001)$, sensory cortex $(p<0.001)$ of untreated $\operatorname{arcA} \beta$ compared to untreated NTLs. A significantly steeper slope was observed for noscapine-treated $\operatorname{arcA} \beta$ compared to untreated $\operatorname{arcA} \beta$ mice in the motor cortex $(p=0.0096)$, sensory cortex $(p<0.0001)$, and thalamus $(p=0.0161)$.

Two-way ANOVA with Tukey's post hoc analysis showed the interaction between brain region and treatment $\times$ genotype with $F(15,2244)=8.3167, p<0.0001$; significantly reduced late $\Delta C B V$ (average of $t=40-46.7 \mathrm{~min}$ ) was observed in untreated $\operatorname{arcA} \beta$ mice compared to untreated NTLs in the motor cortex $(12.5 \pm 8.3$ vs. $28.9 \pm 26.1 \%, p<0.0001)$, sensory cortex $(24.0 \pm 15.1$ vs. 

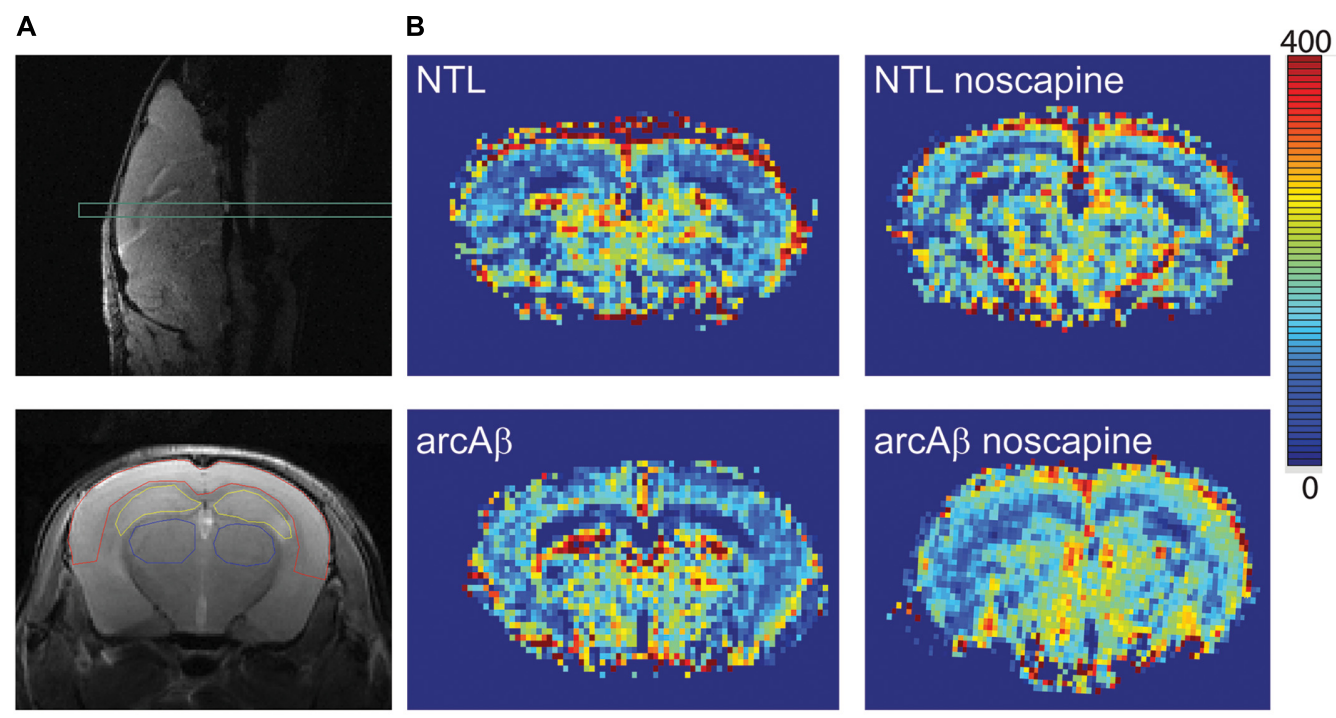

C

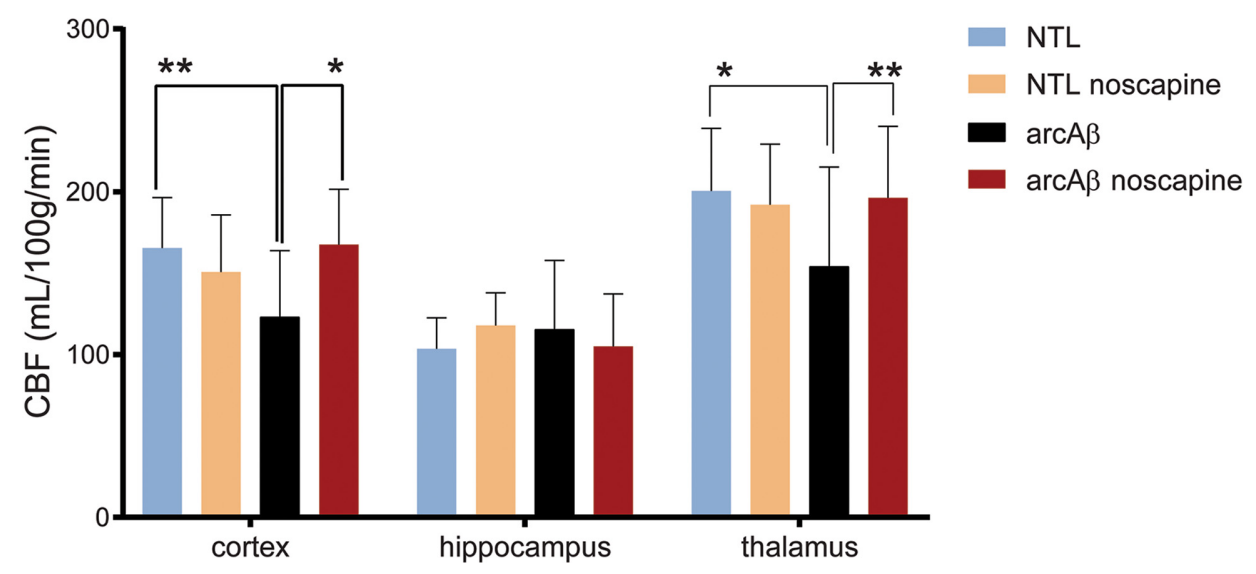

FIGURE 2 | Bradykinin receptor blockade by noscapine alleviates regional hypoperfusion in arcA $\beta$ mice. (A) Anatomical position of slice for arterial spin labeling on sagittal $\mathrm{T}_{2}$-weighted image (top) and representative regions of interest (ROI) [cortex (red), hippocampus (yellow), and thalamus (blue)] on coronal $\mathrm{T}_{2}$-weighted anatomical image acquired at the same position (bottom). (B) Representative coronal CBF maps (approximately Bregma $-1.5 \pm 0.3 \mathrm{~mm}$ ) of untreated and noscapine-NTLs and arcA $\beta$ mice, respectively. (C) Quantification of regional CBF showed hypoperfusion in the cortex and thalamus of arcA $\beta$ compared with NTLs that is mitigated by noscapine treatment. Data are present as mean \pm standard deviation; ${ }^{*} p<0.05$, ** $p<0.01$, two-way ANOVA with post hoc Turkey's correction for multiple comparison; CBF, cerebral blood flow. NTL $(n=8)$, NTL noscapine $(n=9)$, arcA $(n=9)$, arcA $\beta$ noscapine $(n=11)$.

$30.4 \pm 11.8 \%, p=0.0219$ ) (Supplementary Figure 4). Higher late $\triangle \mathrm{CBV}$ was observed in noscapine-treated $\operatorname{arcA} \beta$ compared to untreated $\operatorname{arcA} \beta$ mice in the motor cortex $(24.6 \pm 19.9$ vs. $12.5 \pm 8.3 \%, p<0.0001)$ and hippocampus $(26.9 \pm 17.9$ vs. $21.1 \pm 10.0 \%, p=0.0174)$. Taken together, measurements of CBV upon acetazolamide stimulation showed that noscapine treatment rescued the reduced CVR in cortical and subcortical regions of $\operatorname{arc} \mathrm{A} \beta$ mice.

\section{Noscapine Did Not Affect Microglia Activation and Beta-Amyloid Level}

Previous reports about the effect of $B_{1} R$ and $B_{2} R$ blockade on neuroinflammation and $\mathrm{A} \beta$ load in animal models of $\mathrm{AD}$ have been contradictory. We therefore analyzed microgliosis and $A \beta$ load in all groups of mice by immunohistochemistry (Figure 5). Two-way ANOVA analysis indicated that noscapine treatment had no influence on amyloid burden in the $\operatorname{arcA} \beta$ mice as revealed by quantitative analysis of $6 \mathrm{E} 10$ immunostainings in the cortex (\% 6E10 area, $1.37 \pm 0.42$ vs. $0.97 \pm 0.44, \mathrm{~ns})$ or in the hippocampus ( $1.44 \pm 0.83$ vs. $1.09 \pm 0.59$, ns), Tukey's post hoc analysis $F(1,16)=0.004815, p=0.9455)$. Moreover, microgliosis Ibal immunoreactivity was significantly higher in the cortex $(0.50 \pm 0.32$ vs. $0.19 \pm 0.09, p=0.0279)$ of untreated $\operatorname{arcA} \beta$ mice compared to NTLs, but not in the hippocampus. The microgliosis Ibal immunoreactivity was similar between noscapine-treated and untreated NTLs in the 


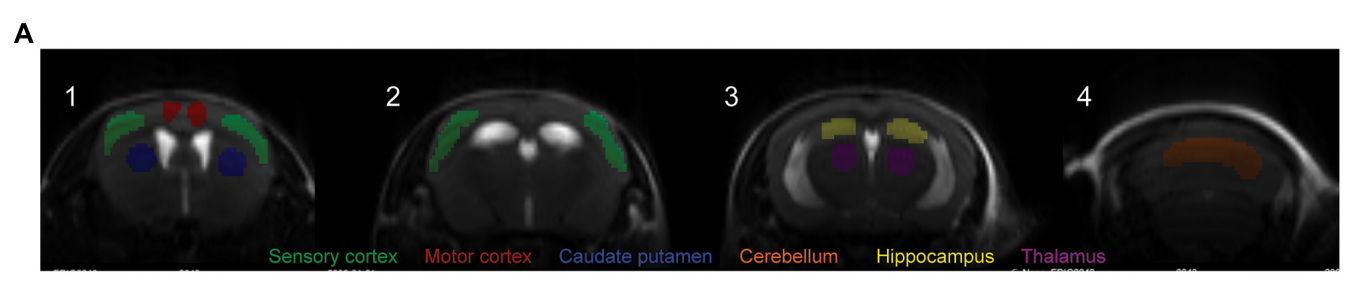

B

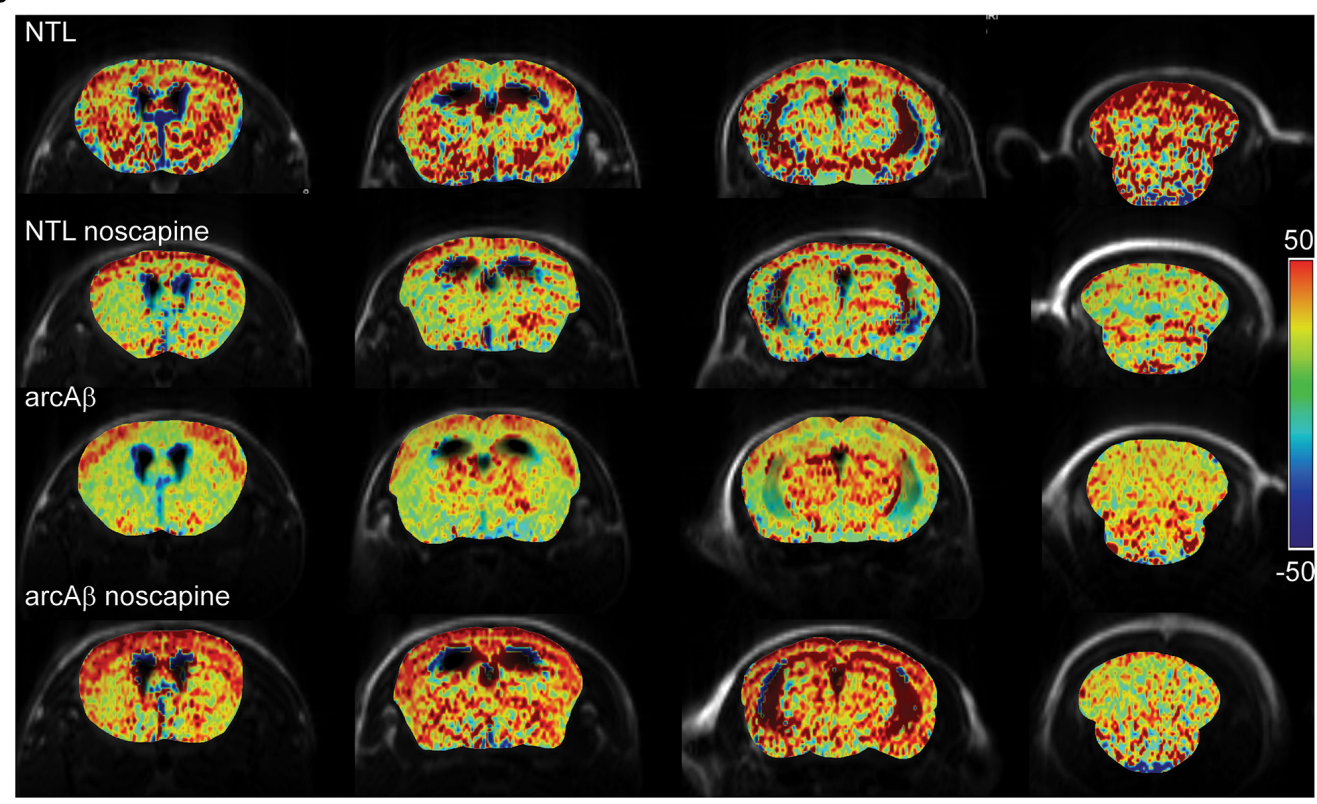

FIGURE 3 | Bradykinin receptor blockade ameliorates the reduced regional cerebral vascular reactivity in noscapine-treated arcA $\beta$ mice. (A) Representative ROI on coronal anatomical $\mathrm{T}_{2}$-weighted MR images at showing the motor cortex, sensory cortex, hippocampus, thalamus, striatum, and cerebellum. (B) Representative maps of percentage change in cerebral blood volume $(\triangle \mathrm{CBV})$ of untreated and noscapine-treated NTLs and arcA $\beta$ mice. Data are present as mean \pm standard deviation; $\triangle \mathrm{CBV}$ : percentage change in CBV.

cortex $(0.18 \pm 0.07$ vs. $0.19 \pm 0.09$, ns $)$, and the hippocampus $(0.10 \pm 0.07$ vs. $0.21 \pm 0.14$, ns); and between noscapinetreated and untreated $\operatorname{arcA} \beta$ mice in the cortex $(0.53 \pm 0.07$ vs. $0.50 \pm 0.32$, ns) and the hippocampus $(0.28 \pm 0.04$ vs. $0.21 \pm 0.14$, ns) [two-way ANOVA with Tukey's post hoc analysis $F(3,34)=1.399, p=0.2599]$. These results suggest that $\mathrm{B}_{1} \mathrm{R}$ and $\mathrm{B}_{2} \mathrm{R}$ blockade with noscapine at this dosage and duration did not alter the amyloid load and degree of $\mathrm{A} \beta$-associated microgliosis.

\section{MSD Analysis}

We used MSD immunoassay to determine $A \beta$ levels in three protein fractions from the brain hemispheres. Two-way ANOVA with Tukey's post hoc analysis showed greater amount of $A \beta_{38}$ (10747.1 \pm 2977.4 vs. $\left.164.8 \pm 57.8, p<0.0001\right)$, $\mathrm{A} \beta_{40}(27222.3 \pm 6376.1$ vs. $35.5 \pm 9.0, p<0.0001)$, and $A \beta_{42}(2679.3 \pm 737.7$ vs. $14.3 \pm 4.7, p<0.0001)$ in FA fractions brain homogenates (Figure 6) from $\operatorname{arcA} \beta$ mice $(n=7)$ compared to NTLs $(n=6)$. No significant difference was detected in the level of $A \beta_{38}$, $\mathrm{A} \beta_{40}$ and $\mathrm{A} \beta_{42}$ in TBS, SDS, and FA fractions between noscapine-treated $\operatorname{arcA} \beta$ mice $(n=4)$ and untreated $\operatorname{arcA} \beta$ mice $(n=7)$.

\section{DISCUSSION}

In the current study, we showed using fMRI techniques a pronounced vascular dysfunction in the $\operatorname{arcA} \beta$ mouse model of cerebral amyloidosis. Chronic administration of $\mathrm{B}_{1} \mathrm{R}$ and $\mathrm{B}_{2} \mathrm{R}$ antagonist noscapine ameliorated amyloidosis-associated cerebral hypoperfusion and vascular reactivity, but did not affect A $\beta$ cerebral load and associated microgliosis.

\section{Activation of the Kallikrein-Kinin System in a Transgenic Mouse Model of Cerebral Amyloidosis}

The kallikrein-kinin system has been shown to be activated both in patients with $\mathrm{AD}$ and in animal disease models (Bergamaschini et al., 1998; Viel and Buck, 2011; Lacoste et al., 2013). In the central nervous system, BRs are mainly distributed in the cortex and hippocampus, the brain structures that are affected earliest by AD pathologies (Jong et al., 2002; Ashby et al., 2012). In the brain $B_{1} R$ and $B_{2} R$ are expressed in a variety of cells including neurons, astrocytes, microglia, oligodendrocytes, and endothelial cells. Upregulation of brain BR levels was shown in rats (Viel et al., 2008), mice (Prediger et al., 2008) in response 
A

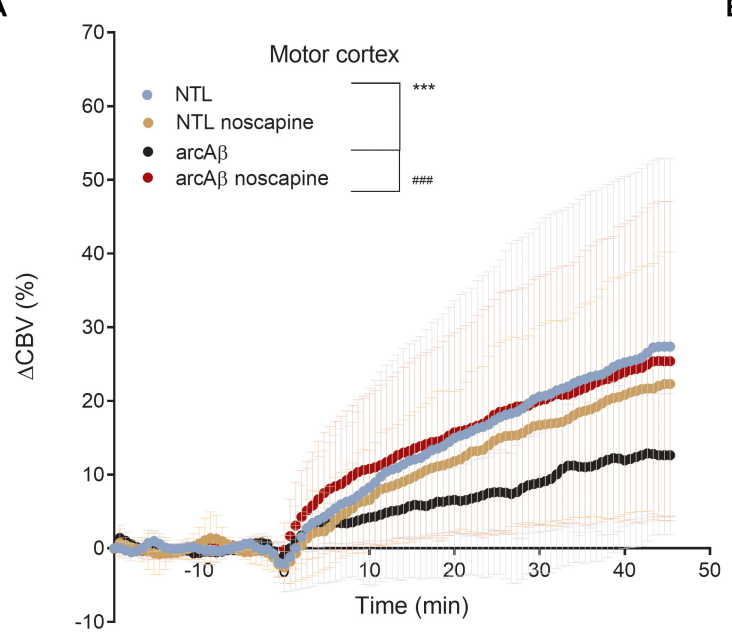

B

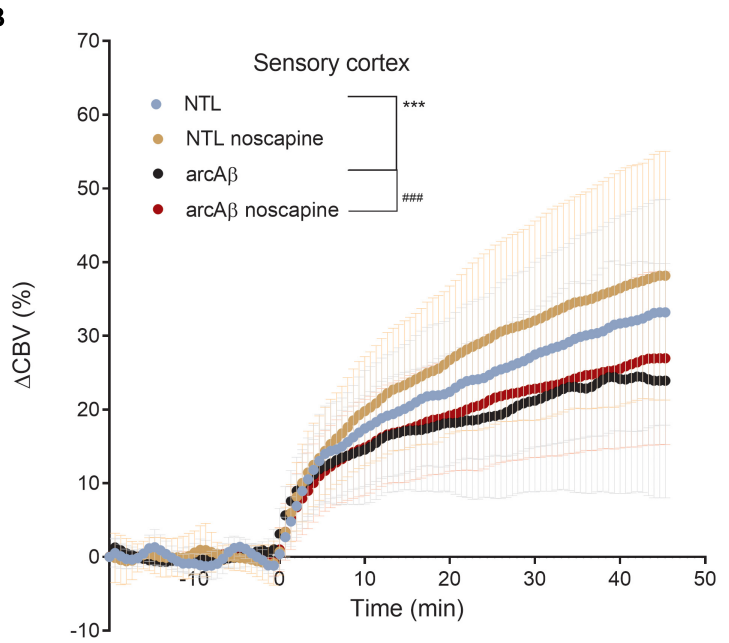

D

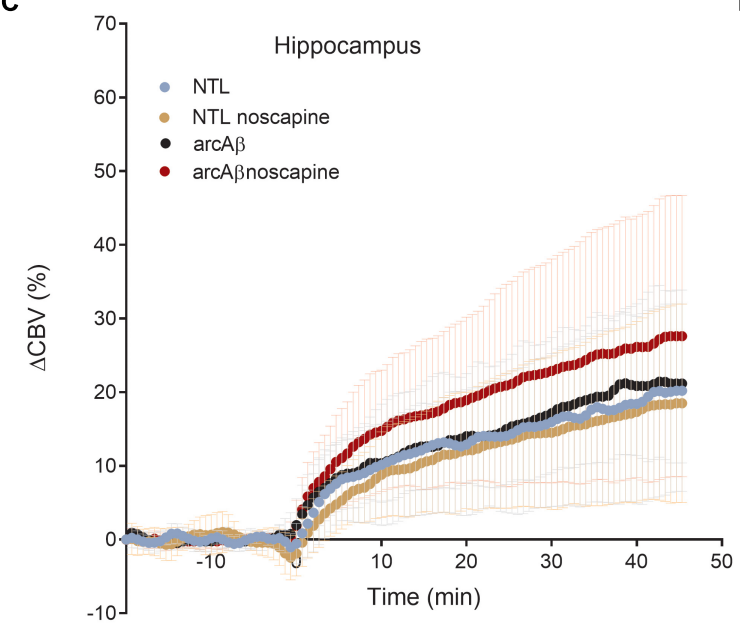

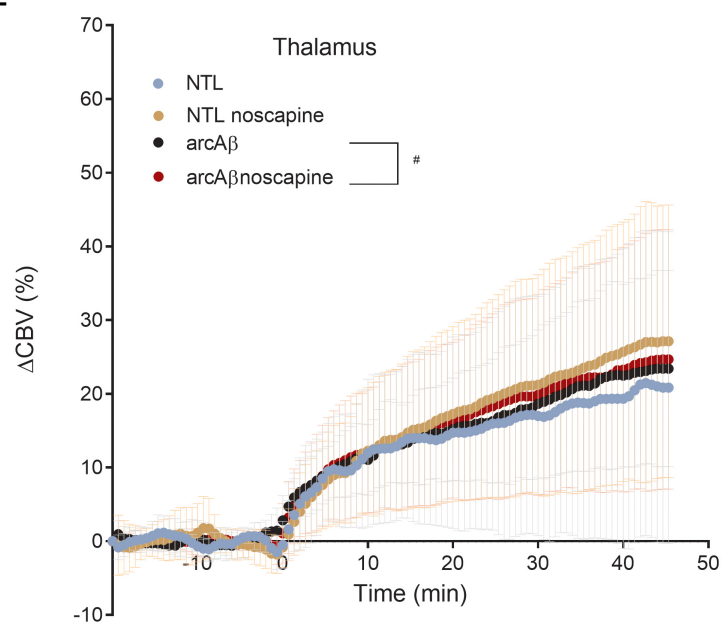
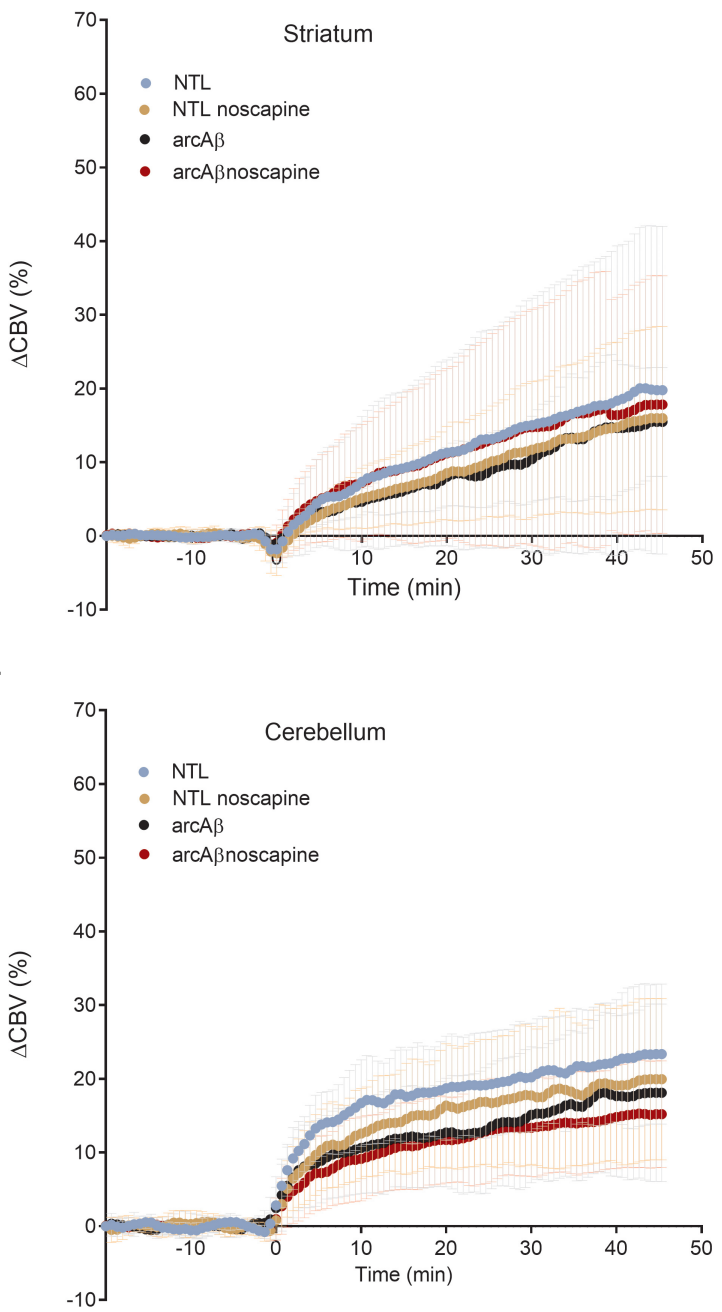

FIGURE 4 | Regional cerebral vascular reactivity in mouse brain. (A-F) Percent change in cerebral blood volume ( $\triangle \mathrm{CBV}$ ) plotted as a function of time for six brain regions (motor cortex, sensory cortex, hippocampus, striatum, thalamus, and cerebellum) of untreated and noscapine-treated NTLs and arcA $\beta$ mice, respectively. Injection of acetazolamide at $t=0$ minute. Data are present as mean \pm standard deviation; ${ }^{* * *} p<0.001$ NTL vs. arcA $\beta,{ }^{\#} p<0.05$, \#\# $p<0.01$, and ${ }^{\# \# \# ~} p<0.001$ $\operatorname{arcA} \beta$ vs. arcA $\beta$-noscapine, two-way ANOVA with post hoc Tukey's correction for multiple comparison. NTL $(n=8)$, NTL noscapine $(n=9)$, arcA $\beta(n=9)$, and arcA $\beta$ noscapine $(n=11)$. 
TABLE 2 | Linear regression analysis of square root ( $\triangle$ CBV\%) along with time in mice.

\begin{tabular}{|c|c|c|c|c|c|}
\hline \multicolumn{2}{|c|}{ Region } & \multirow{2}{*}{$\begin{array}{c}\text { NTL } \\
0.061 \pm 0.002\end{array}$} & \multirow{2}{*}{$\begin{array}{c}\text { NTL noscapine } \\
0.066 \pm 0.002\end{array}$} & \multirow{2}{*}{$\begin{array}{c}\operatorname{arcA} \boldsymbol{\beta} \\
0.048 \pm 0.001^{* * *}\end{array}$} & \multirow{2}{*}{$\begin{array}{c}\operatorname{arcA} \beta \text { noscapine } \\
0.057 \pm 0.001^{\# \#}\end{array}$} \\
\hline Motor cortex & Slope & & & & \\
\hline & Intercept & $2.178 \pm 0.056$ & $1.747 \pm 0.047$ & $1.4 \pm 0.023$ & $2.379 \pm 0.037$ \\
\hline & $R$ & 0.9243 & 0.9523 & 0.9773 & 0.9614 \\
\hline \multirow[t]{3}{*}{ Sensory cortex } & Slope & $0.064 \pm 0.003$ & $0.069 \pm 0.004$ & $0.038 \pm 0.002^{* * *}$ & $0.054 \pm 0.003^{\# \# \#}$ \\
\hline & Intercept & $3.120 \pm 0.087$ & $3.383 \pm 0.096$ & $3.164 \pm 0.058$ & $2.989 \pm 0.082$ \\
\hline & $R$ & 0.8462 & 0.8399 & 0.8172 & 0.8162 \\
\hline \multirow[t]{3}{*}{ Hippocampus } & Slope & $0.045 \pm 0.002$ & $0.047 \pm 0.002$ & $0.050 \pm 0.002$ & $0.050 \pm 0.002$ \\
\hline & Intercept & $2.451 \pm 0.047$ & $2.127 \pm 0.055$ & $2.503 \pm 0.048$ & $2.959 \pm 0.066$ \\
\hline & $R$ & 0.9036 & 0.8816 & 0.917 & 0.8556 \\
\hline \multirow[t]{3}{*}{ Thalamus } & Slope & $0.042 \pm 0.002$ & $0.078 \pm 0.003$ & $0.049 \pm 0.002$ & $0.058 \pm 0.002^{\#}$ \\
\hline & Intercept & $2.549 \pm 0.063$ & $2.669 \pm 0.090$ & $2.690 \pm 0.044$ & $2.731 \pm 0.062$ \\
\hline & $R$ & 0.8179 & 0.8829 & 0.9258 & 0.8999 \\
\hline \multirow[t]{3}{*}{ Caudate nucleus } & Slope & $0.054 \pm 0.001$ & $0.065 \pm 0.001$ & $0.059 \pm 0.002$ & $0.053 \pm 0.002$ \\
\hline & Intercept & $1.826 \pm 0.032$ & $1.327 \pm 0.034$ & $1.376 \pm 0.043$ & $1.848 \pm 0.045$ \\
\hline & $R$ & 0.9666 & 0.9744 & 0.9515 & 0.9334 \\
\hline \multirow[t]{3}{*}{ Cerebellum } & Slope & $0.035 \pm 0.003$ & $0.045 \pm 0.003$ & $0.035 \pm 0.001$ & $0.037 \pm 0.002$ \\
\hline & Intercept & $3.342 \pm 0.075$ & $2.946 \pm 0.075$ & $2.619 \pm 0.033$ & $2.429 \pm 0.050$ \\
\hline & $R$ & 0.6884 & 0.7877 & 0.9198 & 0.8486 \\
\hline
\end{tabular}

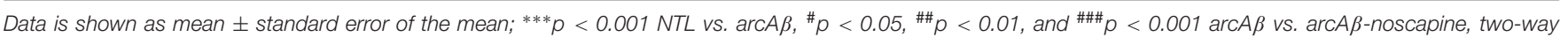
ANOVA with Tukey's post hoc analysis; NTL $(n=8), N T L$ noscapine $(n=9), \operatorname{arcA} \beta(n=9)$, $\operatorname{arcA} \beta$ noscapine $(n=11)$.

to infusion of human $\mathrm{A} \beta$, as well as in transgenic mouse models of cerebral amyloidosis (Lacoste et al., 2013; Passos et al., 2013). Also, increased $B_{2} R$ density was demonstrated by ${ }^{3} \mathrm{H}$-bradykinin binding assay in skin fibroblasts from patients with $\mathrm{AD}$ compared to that from age-matched healthy controls (Noda et al., 2003). In the present study, we showed that $\operatorname{arcA} \beta$ mice of amyloidosis have increased plasma bradykinin levels as compared to NTLs at the endpoint of the study. The $\operatorname{arcA} \beta$ mouse model of cerebral amyloidosis exhibits cerebral plaque deposition from 6 months-of-age together with strong congophilic cerebral amyloid angiopathy (Knobloch et al., 2007) and increased bradykinin plasma levels may likely be due to vascular amyloid deposition.

\section{BRs as Pharmacological Targets in AD}

Previous studies using animal models of $\mathrm{AD}$ have described BRs blockade as a potential treatment strategy for AD. Pharmacological blockade of both BRs in transgenic mice overexpressing amyloid precursor protein or mice infused with $A \beta$ has been shown to improve learning and memory formation. $\mathrm{B}_{1} \mathrm{R}$ blockade mitigated cognitive deficits by $\mathrm{B}_{1} \mathrm{R}$ antagonist des-Arg9[Leu8]-bradykinin in A $\beta$-treated mice (Prediger et al., 2008) and in rat (Bitencourt et al., 2017), and by $B_{1} R$ antagonist SSR240612 in Tg-SwDI mice of AD (Lacoste et al., 2013). $B_{2} R$ blockade by HOE 140 protected against cognitive impartment in A $\beta$-infused mice (Prediger et al., 2008; Bicca et al., 2015).

It has been described that $\mathrm{B}_{2} \mathrm{Rs}$ are constitutively expressed and mediate most physiological actions of kinins, whereas $\mathrm{B}_{1}$ Rs are highly inducible upon inflammatory stimulation and tissue injury (Marceau et al., 2002). Thus, the majority of previous preclinical studies have focused on $B_{1} R$ inhibition. However, it has been described that the expression of both receptors is increased under pathological conditions related to oxidative stress, pro-inflammatory stimuli (e.g., inflammation and infection) as well as vasoactive peptides of the reninangiotensin system (Nokkari et al., 2018). Thus, we have used noscapine a phthalideisoquinoline alkaloid, which is an antagonist for both $\mathrm{B}_{1} \mathrm{R}$ and $\mathrm{B}_{2} \mathrm{R}(\mathrm{pA} 2=6.68)$ (Mahmoudian and Mojaverian, 2001). We decided to provide the drug in drinking water as an easy administrable way for chronic pharmacological treatment, but which might have introduced variability in the treatment effect due to different uptake of the drug by the mice. Noscapine has been clinically approved as antitussive drug, and has the advantage that it can be administered orally, that its pharmacokinetics and metabolic fate are characterized, and that it has low toxicity (Empey et al., 1979; Tsunoda and Yoshimura, 1979; Karlsson et al., 1990).

\section{Blockade of $B_{1} R$ and $B_{2} R$ Ameliorates Cerebrovascular Dysfunction}

We used established functional MRI protocols to assess the effects of noscapine treatment on cerebrovascular dysfunction in vivo (Klohs et al., 2014; Ni et al., 2018a). Cerebrovascular dysfunction is an early pathological event in patients with $\mathrm{AD}$ (Iturria-Medina et al., 2016). The brain critically depends on the continuous supply of oxygen and nutrients for proper cognitive function, and thus CBF is a tightly regulated process. In a previous study it was shown with Laser Doppler flowmetry in the J20 mouse model that blockade of $\mathrm{B}_{1} \mathrm{R}$ improves $\mathrm{CBF}$ (Lacoste et al., 2013). We have assessed CBF using a non-invasive arterial spin labeling technique. We showed a $25 \%$ reduction in $\mathrm{CBF}$ in the cortex of approximately 17-months-old $\operatorname{arcA} \beta$ mice compared to age-matched NTLs. In a previous study using the same fMRI technique we found normal CBV values in 6-months-old $\operatorname{arcA} \beta$ 

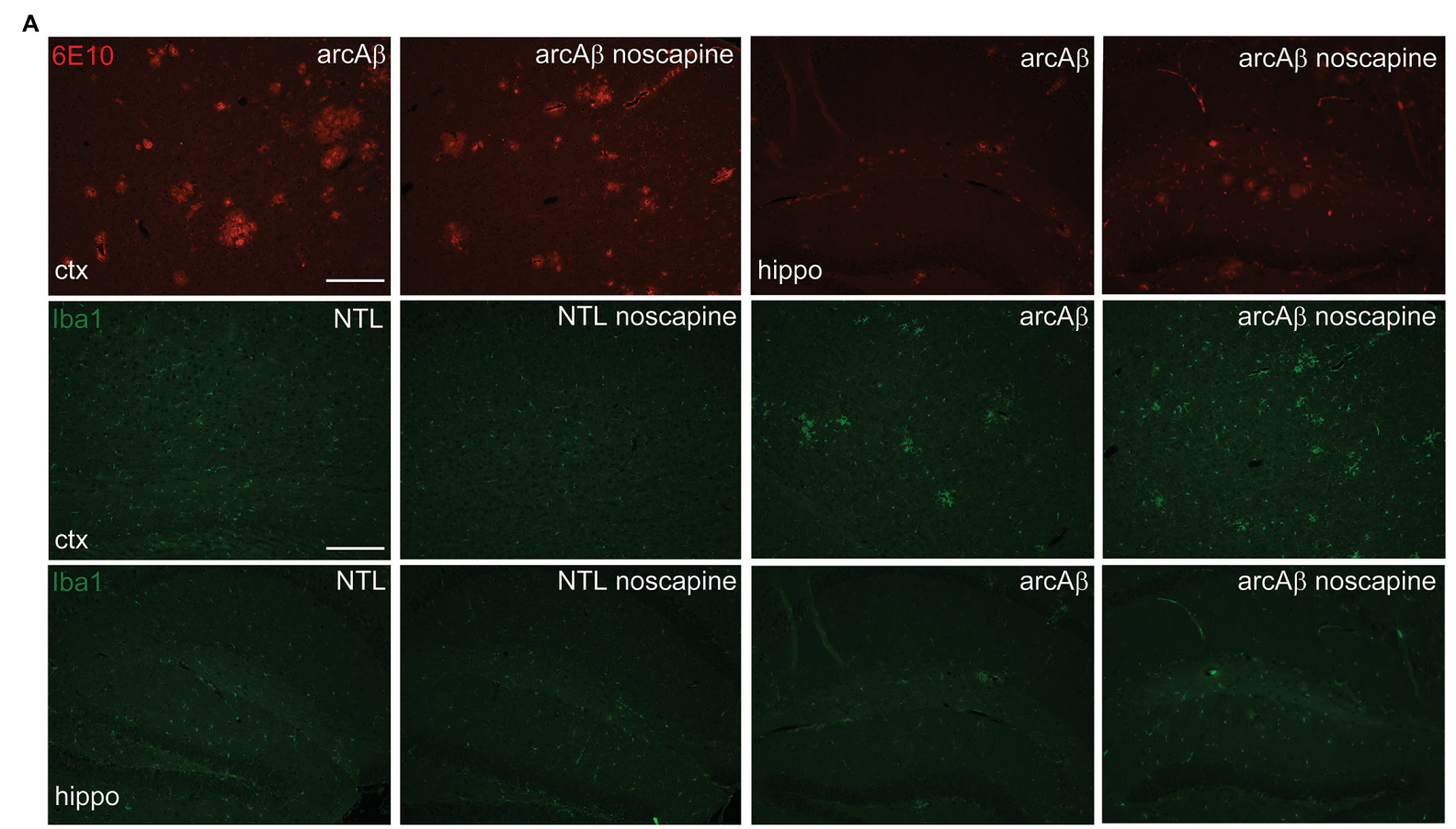

B
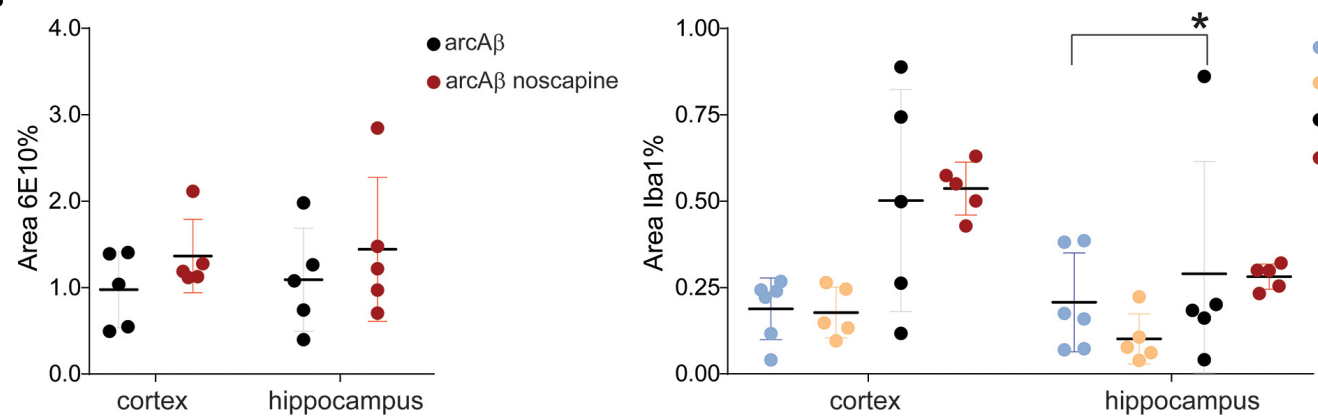

FIGURE 5 | Immunohistochemical analysis of A $\beta$ load and microglia activation. (A) Brain tissue sections of untreated and noscapine-treated NTLs and arcA $\beta$ mice were stained for amyloid (6E10, red), microglia (Iba1, green) immunoreactivity in the cortex (ctx) and hippocampus (hippo) of untreated and noscapine-treated NTLs and $\operatorname{arcA\beta }$ mice, respectively. Scale bar $=400 \mu \mathrm{m}$. (B) Quantification of immunoreactivity. Data are present as mean \pm standard deviation; Iba1: ionized calcium-binding adapter molecule $1 .{ }^{*} p<0.05$, two-way ANOVA with Tukey's post hoc correction for multiple comparison. NTL $(n=5)$, NTL noscapine $(n=5)$, $\operatorname{arcA} \beta(n=5)$, and $\operatorname{arcA} \beta$ noscapine $(n=5)$.

mice and a $30 \%$ reduction in $\mathrm{CBF}$ in the cortex of 24-months-old $\operatorname{arcA} \beta$ mice compared to NTLs (Ni et al., 2018b), which indicates that the severity of the CBF reduction increased with increasing age in that mouse model. With perfusion MRI, we observed that noscapine treatment reversed the pathological hypoperfusion in the cortex and thalamus in $\operatorname{arc} \mathrm{A} \beta$ mice.

Cerebral vascular reactivity reflects the capacity of blood vessels to dilate and is an important indicator of the brain vascular reserve capacity. Dynamic measurement of CBV upon acetazolamide challenge is commonly used in humans and animals for quantification of CVR and has shown to be impaired in $\mathrm{AD}$ patients and models of cerebral amyloidosis (Stoppe et al., 1995; Mueggler et al., 2002; Princz-Kranz et al., 2010; Dumas et al., 2012). Acetazolamide inhibits carbonic anhydrase, which results into increased $\mathrm{CBV}$, but its exact mode of action is not yet clear (Vorstrup et al., 1984; Dumas et al., 2012). In our study we observed a global reduction in CVR in the cortical and subcortical regions in untreated $\operatorname{arcA} \beta$ mice compared to NTLs. A previous fMRI study has described a reduction of CVR in cortical regions but not subcortical regions in 16-months-old $\operatorname{arcA} \beta$ mice that was aggravated with aging (Princz-Kranz et al., 2010). These differences in CVR in subcortical regions of $\operatorname{arcA} \beta$ mice might be due to the fact that mice although being of the same strain were from different colonies. Biological factors such as genetic backgrounds (our $\operatorname{arcA} \beta$ mice were derived from transgenic mouse strain back-crossed to C57BL6 for over 10 generations compared to mice in the previous study which had been on a mixed genetic background) and environmental factors such as housing conditions can affect the phenotype. In the current study we found that treatment with noscapine ameliorated CVR 


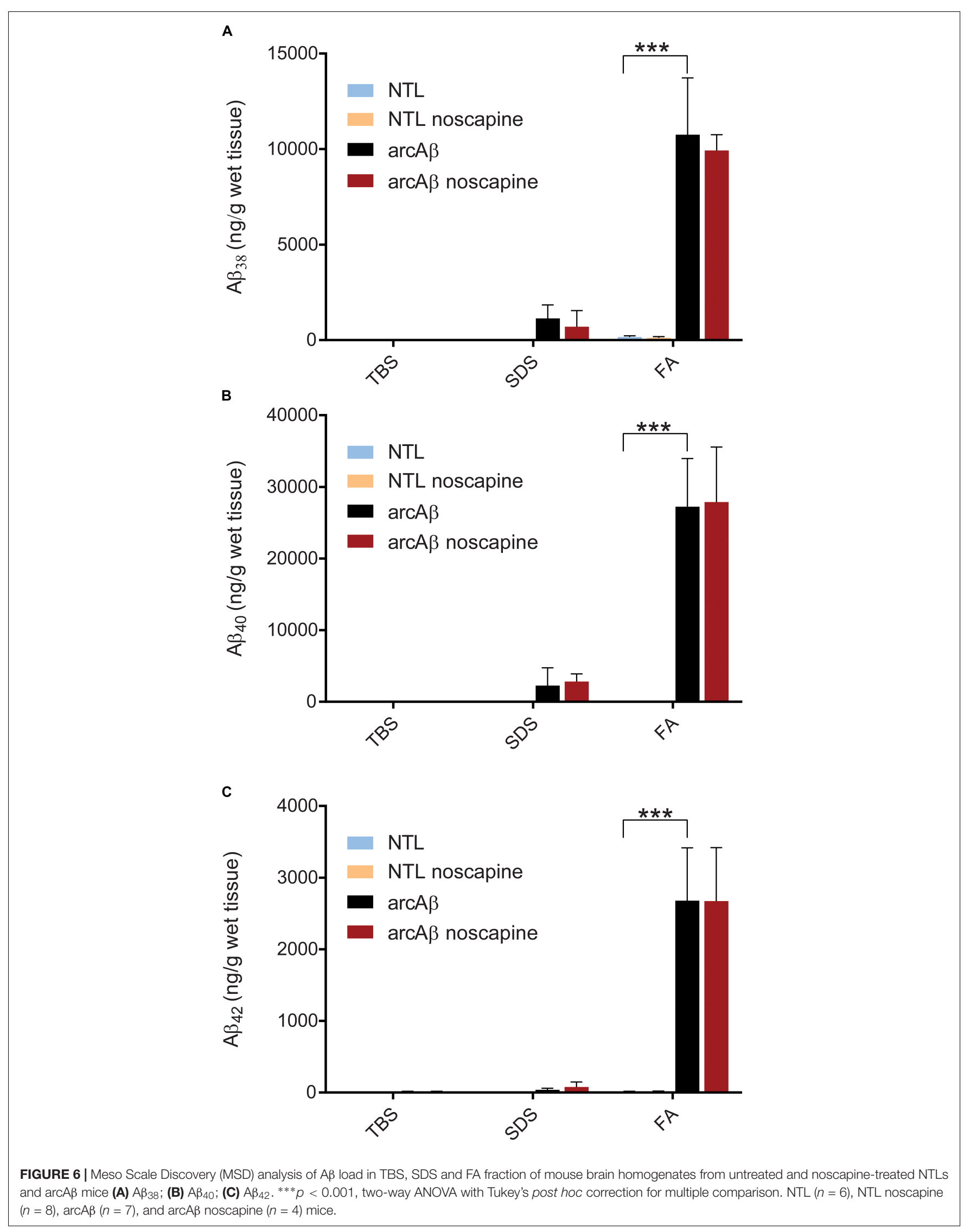


reduction in $\operatorname{arc} A \beta$ mice, which is in line with a previous study that blockade of $\mathrm{B}_{1} \mathrm{R}$ significantly ameliorated sensory-evoked hemodynamic responses in the J20 mouse model (Lacoste et al., 2013). As inhibition of BRs can affect the angiotensin system (AbdAlla et al., 2001; Jing et al., 2012), we measured systolic and diastolic blood pressure between groups. As we did not observe differences in blood pressure values among groups, we ruled out that the observed $\triangle \mathrm{CBV}$ differences were due to actions of noscapine on the angiotensin system.

The findings from $\mathrm{CVR}$ and $\mathrm{CBF}$ measurement clearly demonstrate that inhibition of $\mathrm{B}_{1} \mathrm{R}$ and $\mathrm{B}_{2} \mathrm{R}$ ameliorate $\mathrm{A} \beta$-induced cerebrovascular dysfunction. The molecular mechanisms underlying cerebrovascular dysfunction in $\mathrm{AD}$ are not well-understood and it can only be speculated how noscapine treatment ameliorated hypoperfusion and reduced CVR in $\operatorname{arcA} \beta$ mice. It has been suggested that blockade of BRs antagonized the production of vascular reactive oxygen species and inflammatory cytokines (Lacoste et al., 2013; Nokkari et al., 2018), which might have contributed to the restoration of the vascular reactivity (Klohs et al., 2012).

\section{Blockade of $B_{1} R$ and $B_{2} R$ Does Not Alter Neuropathology}

In addition to functional vascular effects of noscapine treatment, we also assessed the effects on neuroinflammation and $A \beta$ pathology. Gliosis is an early phenomenon both in mouse models of amyloidosis (Rodriguez-Vieitez et al., 2015; Lopez-Picon et al., 2018) and in patients with AD (Heneka et al., 2015). Activated microglia surrounding amyloid deposits and upregulated proinflammatory cytokines have been reported in the $\operatorname{arcA} \beta$ mice (Knobloch et al., 2007; Klohs et al., 2012) and we have seen also microglia activation in the brains of noscapine-treated and untreated $\operatorname{arc} \mathrm{A} \beta$ mice.

$\mathrm{B}_{1} \mathrm{R}$ is involved in inflammation in the central nervous system mainly through the activation of microglia (Asraf et al., 2017) and astrocytes (Lacoste et al., 2013). However, the effects of bradykinin inhibition on microglia and astrocytes have been inconsistent, both suppression (Bitencourt et al., 2017) and stimulation (Asraf et al., 2016) of neuroinflammation has been reported, or showed no effect (Asraf et al., 2016). Using measurements of Ibal immunoreactivity in few selected animals from each group, we found no effect of chronic oral noscapine treatment on microglia activation. In the current study, we have used Ibal immunoreactivity as a rough estimate of neuroinflammation and have not attempted to discriminate the different types of microglia (resting and activated), which would require a more elaborate histological analysis. In addition, other markers of neuroinflammation (for example GFAP, CD68, etc.) and larger groups of animals might be investigated.

Reports on the effect of $B_{1} R$ and $B_{2} R$ on $A \beta$ load have also been contradictory. $\mathrm{B}_{2} \mathrm{R}$ activation promoted $\alpha$-secretase processing of amyloid precursor protein in skin fibroblasts from patients with $\mathrm{AD}$, resulting in a lower production of $\mathrm{A} \beta$ (Nitsch et al., 1998). $\mathrm{B}_{1} \mathrm{R}$ antagonist SSR240612 reduced $\mathrm{A} \beta$ deposition (Lacoste et al., 2013) in Tg-SwDI mouse model of AD amyloidosis, while another $B_{1} R$ antagonist R-715 treatment increased $A \beta_{40}$ and fibrillar $\mathrm{A} \beta$ deposition in both transgenic mouse models of $\mathrm{AD}$, Tg-SwDI (Passos et al., 2013) and $5 \times$ familial mice (Asraf et al., 2016). A $\beta$ can in turn activate the release of kinins in cultured endothelial cells (Joseph et al., 1999). In our study, using immunohistochemical analysis of brain section and MSD immunoassay of brain tissue we found no effect of inhibition of $B_{1} R$ and $B_{2} R$ inhibition on cerebral $A \beta$ load.

\section{Methodological Considerations}

The reported differences in the action of bradykinin receptor inhibitors might be due to the affinity of individual inhibitors to $\mathrm{B}_{1} \mathrm{R}$ and $\mathrm{B}_{2} \mathrm{R}$, as well as other factors like pharmacokinetics, biodistribution of the drug used, and the timing, dose and duration of the treatment. In our study, we found amelioration of cerebrovascular dysfunction with chronic oral noscapine treatment, while the treatment seemed to have no effects on cerebral $A \beta$ load and microglia activation. In that context, fMRI could constitute a more sensitive and earlier indicator of treatment response than histological or biochemical assessment. It might be, however, conceivable that a different dose of noscapine or longer treatment periods might have also led to detectable changes in neuropathology. In addition, we started treatment in $\operatorname{arcA} \beta$ mice at an advanced disease stage, which limited the potential effect scale on the different read-outs. Importantly, we have not used behavioral read-outs to assess effects of noscapine treatment on the cognitive deficit in $\operatorname{arcA} \beta$ mice (Knobloch et al., 2007) and thus do not know if noscapine has led to an improvement of cognitive function. Thus, more extensive studies using additional behavioral readouts, and starting treatment at an early disease stage are needed to demonstrate the full potential of noscapine treatment on AD pathology.

\section{CONCLUSION}

Long-term oral noscapine treatment alleviates brain hypoperfusion and restores CVR in an animal model of amyloidosis as revealed by fMRI. Blocking BRs represents a potential target for treatment of $\mathrm{AD}$-associated cerebrovascular dysfunction.

\section{AVAILABILITY OF DATA AND MATERIAL}

The datasets generated and/or analyzed during the current study are available in the repository http://doi.org/10.5281/zenodo. 1209065.

\section{AUTHOR CONTRIBUTIONS}

RuN, LK, and JK conceived and designed the study and interpreted the results. RuN, DK, LL, and RW performed the experiments. RuN, RW, LL, LK, and JK analyzed the data. RuN and JK wrote the paper. All coauthors contributed constructively to the manuscript. 


\section{FUNDING}

This work was funded by the University of Zurich and the ETH Zurich Foundation through a seed grant of "University Medicine Zurich/Hochschulmedizin Zürich", from the Olga Mayenfisch Stiftung, Hartmann Muller Stiftung and University of Zurich Forschungskredit (Nr. FK-17-052).

\section{ACKNOWLEDGMENTS}

The authors thank Prof. Bernhard Lämmle Emeritus Professor and Director at Inselspital Universitätsklinik für Hämatologie, Bern \& guest professor Centrum für Thrombose und Hämostase,

\section{REFERENCES}

AbdAlla, S., Lother, H., El Massiery, A., and Quitterer, U. (2001). Increased AT1 receptor heterodimers in preeclampsia mediate enhanced angiotensin II responsiveness. Nat. Med. 7:1003. doi: 10.1038/nm0901-1003

Ashby, E. L., Love, S., and Kehoe, P. G. (2012). Assessment of activation of the plasma kallikrein-kinin system in frontal and temporal cortex in Alzheimer's disease and vascular dementia. Neurobiol. Aging 33, 1345-1355. doi: 10.1016/j. neurobiolaging.2010.09.024

Asraf, K., Torika, N., Danon, A., and Fleisher-Berkovich, S. (2017). Involvement of the Bradykinin B1 Receptor in microglial activation: in vitro and in vivo studies. Front. Endocrinol. 8:82. doi: 10.3389/fendo.2017.00082

Asraf, K., Torika, N., Roasso, E., and Fleisher-Berkovich, S. (2016). Differential effect of intranasally administrated kinin B1 and B2 receptor antagonists in Alzheimer's disease mice. Biol. Chem. 397, 345-351. doi: 10.1515/hsz-20150219

Bergamaschini, L., Parnetti, L., Pareyson, D., Canziani, S., Cugno, M., and Agostoni, A. (1998). Activation of the contact system in cerebrospinal fluid of patients with Alzheimer disease. Alzheimer Dis. Assoc. Disord. 12, 102-108. doi: 10.1097/00002093-199806000-00008

Bicca, M. A., Costa, R., Loch-Neckel, G., Figueiredo, C. P., Medeiros, R., and Calixto, J. B. (2015). B(2) receptor blockage prevents $A \beta$-induced cognitive impairment by neuroinflammation inhibition. Behav. Brain Res. 278, 482-491. doi: 10.1016/j.bbr.2014.10.040

Bitencourt, R. M., Guerra De Souza, A. C., Bicca, M. A., Pamplona, F. A., De Mello, N., Passos, G. F., et al. (2017). Blockade of hippocampal bradykinin B1 receptors improves spatial learning and memory deficits in middle-aged rats. Behav. Brain Res. 316, 74-81. doi: 10.1016/j.bbr.2016.08.041

Braak, H., and Braak, E. (1991). Neuropathological stageing of Alzheimer-related changes. Acta Neuropathol. 82, 239-259. doi: 10.1007/BF00308809

Caetano, A. L., Dong-Creste, K. E., Amaral, F. A., Monteiro-Silva, K. C., Pesquero, J. B., Araujo, M. S., et al. (2015). Kinin B2 receptor can play a neuroprotective role in Alzheimer's disease. Neuropeptides 53, 51-62. doi: 10.1016/j.npep.2015. 09.001

Couture, R., Lindsey, C., Quirion, R., Bjorklund, A., and Hokfelt, T. (2000). Brain kallikrein- kinin system: from receptors to neuronal pathways and physiological functions. Handb. Chem. Neuroanat. 16, 241-300. doi: 10.1016/S0924-8196(00) 80009-3

de la Torre, J. C. (2004). Is Alzheimer's disease a neurodegenerative or a vascular disorder? Data, dogma, and dialectics. Lancet Neurol. 3, 184-190. doi: 10.1016/ S1474-4422(04)00683-0

Dumas, A., Dierksen, G. A., Gurol, M. E., Halpin, A., Martinez-Ramirez, S., Schwab, K., et al. (2012). Functional MRI detection of vascular reactivity in cerebral amyloid angiopathy. Ann. Neurol. 72, 76-81. doi: 10.1002/ana.23566

Empey, D. W., Laitinen, L. A., Young, G. A., Bye, C. E., and Hughes, D. T. (1979). Comparison of the antitussive effects of codeine phosphate $20 \mathrm{mg}$, dextromethorphan $30 \mathrm{mg}$ and noscapine $30 \mathrm{mg}$ using citric acid-induced cough in normal subjects. Eur. J. Clin. Pharmacol. 16, 393-397. doi: 10.1007/ BF00568199
Universitätsmedizin Mainz for constructive advices on the manuscript; Dr. Mark Augath and Jael Xandry at Institute for Biomedical Engineering, ETH Zurich \& University of Zurich, Dr. Linjing $\mathrm{Mu}$ at Institute of Pharmacology, ETH Zurich, Susanne Freedrich and Johnathan Ward at EPIC, ETH Zurich for technical support; Dr. Andreas Steingötter ETH Zurich for statistic consultation.

\section{SUPPLEMENTARY MATERIAL}

The Supplementary Material for this article can be found online at: https://www.frontiersin.org/articles/10.3389/fnagi. 2019.00027/full\#supplementary-material

Frisoni, G. B., Fox, N. C., Jack, C. R. Jr., Scheltens, P., and Thompson, P. M. (2010). The clinical use of structural MRI in Alzheimer disease. Nat. Rev. Neurol. 6 , 67-77. doi: 10.1038/nrneurol.2009.215

Heneka, M. T., Carson, M. J., El Khoury, J., Landreth, G. E., Brosseron, F., Feinstein, D. L., et al. (2015). Neuroinflammation in Alzheimer's disease. Lancet Neurol. 14, 388-405. doi: 10.1016/S1474-4422(15)70016-5

Iturria-Medina, Y., Sotero, R. C., Toussaint, P. J., Mateos-Perez, J. M., and Evans, A. C. (2016). Early role of vascular dysregulation on late-onset Alzheimer's disease based on multifactorial data-driven analysis. Nat. Commun. 7:11934. doi: $10.1038 /$ ncomms 11934

Jing, F., Mogi, M., Sakata, A., Iwanami, J., Tsukuda, K., Ohshima, K., et al. (2012). Direct stimulation of angiotensin II type 2 receptor enhances spatial memory. J. Cereb. Blood Flow Metab. 32, 248-255. doi: 10.1038/jcbfm.2011.133

Jong, Y., Dalemar, L., Seehra, K., and Baenziger, N. (2002). Bradykinin receptor modulation in cellular models of aging and Alzheimer's disease. Int. Immunopharmacol. 2, 1833-1840. doi: 10.1016/S1567-5769(02)00168-6

Joseph, K., Shibayama, Y., Nakazawa, Y., Peerschke, E., Ghebrehiwet, B., and Kaplan, A. (1999). Interaction of factor XII and high molecular weight kininogen with cytokeratin 1 and gClqR of vascular endothelial cells and with aggregated Abeta protein of Alzheimer's disease. Immunopharmacology 42, 203-210. doi: 10.1016/S0162-3109(99)00136-8

Karlsson, M. O., Dahlstrom, B., Eckernas, S. A., Johansson, M., and Alm, A. T. (1990). Pharmacokinetics of oral noscapine. Eur. J. Clin. Pharmacol. 39, 275279. doi: $10.1007 / \mathrm{BF} 00315110$

Kisler, K., Nelson, A. R., Montagne, A., and Zlokovic, B. V. (2017). Cerebral blood flow regulation and neurovascular dysfunction in Alzheimer disease. Nat. Rev. Neurosci. 18, 419-434. doi: 10.1038/nrn.2017.48

Klohs, J., Baltes, C., Princz-Kranz, F., Ratering, D., Nitsch, R. M., Knuesel, I., et al. (2012). Contrast-enhanced magnetic resonance microangiography reveals remodeling of the cerebral microvasculature in transgenic ArcAbeta mice. J. Neurosci. 32, 1705-1713. doi: 10.1523/JNEUROSCI.562611.2012

Klohs, J., Deistung, A., Ielacqua, G., Seuwen, A., Kindler, D., Schweser, F., et al. (2016). Quantitative assessment of microvasculopathy in $\operatorname{arcA} \beta$ mice with USPIO-enhanced gradient echo MRI. J. Cereb. Blood Flow Metab. 36, 16141624. doi: $10.1177 / 0271678$ X15621500

Klohs, J., Rudin, M., Shimshek, D. R., and Beckmann, N. (2014). Imaging of cerebrovascular pathology in animal models of Alzheimer's disease. Front. Aging Neurosci. 6:32. doi: 10.3389/fnagi.2014.00032

Knobloch, M., Konietzko, U., Krebs, D., and Nitsch, R. (2007). Intracellular Abeta and cognitive deficits precede beta-amyloid deposition in transgenic arcAbeta mice. Neurobiol. Aging 28, 1297-1306. doi: 10.1016/j.neurobiolaging.2006.06. 019

Kulic, L., Mcafoose, J., Welt, T., Tackenberg, C., Spani, C., Wirth, F., et al. (2012). Early accumulation of intracellular fibrillar oligomers and late congophilic amyloid angiopathy in mice expressing the Osaka intra-Abeta APP mutation. Transl. Psychiatry 2:e183. doi: 10.1038/tp.2012.109

Lacoste, B., Tong, X. K., Lahjouji, K., Couture, R., and Hamel, E. (2013). Cognitive and cerebrovascular improvements following kinin B1 receptor blockade in 
Alzheimer's disease mice. J. Neuroinflammation 10:57. doi: 10.1186/17422094-10-57

Landen, J. W., Hau, V., Wang, M., Davis, T., Ciliax, B., Wainer, B. H., et al. (2004). Noscapine crosses the blood-brain barrier and inhibits glioblastoma growth. Clin. Cancer Res. 10, 5187-5201. doi: 10.1158/1078-0432.CCR-04-0360

Leithner, C., Gertz, K., Schrock, H., Priller, J., Prass, K., Steinbrink, J., et al. (2008). A flow sensitive alternating inversion recovery (FAIR)-MRI protocol to measure hemispheric cerebral blood flow in a mouse stroke model. Exp. Neurol. 210, 118-127. doi: 10.1016/j.expneurol.2007.10.003

Lopez-Picon, F. R., Snellman, A., Eskola, O., Helin, S., Solin, O., HaaparantaSolin, M., et al. (2018). Neuroinflammation appears early on PET imaging and then plateaus in a mouse model of Alzheimer Disease. J. Nuclic Med. 59, 509-515. doi: 10.2967/jnumed.117.197608

Mahmoudian, M., and Mojaverian, N. (2001). Efffect of noscapine, the antitussive opioid alkaloid, on bradykinin-induced smooth muscle contraction in the isolated ileum of the guinea-pig. Acta Physiol. Hung. 88, 231-237. doi: 10.1556/ APhysiol.88.2001.3-4.5

Maier, F. C., Wehrl, H. F., Schmid, A. M., Mannheim, J. G., Wiehr, S., Lerdkrai, C., et al. (2014). Longitudinal PET-MRI reveals beta-amyloid deposition and rCBF dynamics and connects vascular amyloidosis to quantitative loss of perfusion. Nat. Med. 20, 1485-1492. doi: 10.1038/nm.3734

Marceau, F., Sabourin, T., Houle, S., Fortin, J., Petitclerc, E., Molinaro, G., et al. (2002). Kinin receptors: functional aspects. Int. Immunopharmacol. 2, 17291739. doi: $10.1016 /$ S1567-5769(02)00189-3

Merlini, M., Meyer, E. P., Ulmann-Schuler, A., and Nitsch, R. M. (2011). Vascular beta-amyloid and early astrocyte alterations impair cerebrovascular function and cerebral metabolism in transgenic arcAbeta mice. Acta Neuropathol. 122, 293-311. doi: 10.1007/s00401-011-0834-y

Montagne, A., Zhao, Z., and Zlokovic, B. (2017). Alzheimer's disease: a matter of blood-brain barrier dysfunction? J. Exp. Med. 214, 3151-3169. doi: 10.1084/jem. 20171406

Mueggler, T., Sturchler-Pierrat, C., Baumann, D., Rausch, M., Staufenbiel, M., and Rudin, M. (2002). Compromised hemodynamic response in amyloid precursor protein transgenic mice. J. Neurosci. 22, 7218-7224. doi: 10.1523/JNEUROSCI. 22-16-07218.2002

Ni, R., Rudin, M., and Klohs, J. (2018a). Cortical hypoperfusion and reduced cerebral metabolic rate of oxygen in the arcAbeta mouse model of Alzheimer's disease. Photoacoustics 10, 38-47. doi: 10.1016/j.pacs.2018.04.001

Ni, R., Vaas, M., Rudin, M., and Klohs, J. (2018b). "Quantification of amyloid deposits and oxygen extraction fraction in the brain with multispectral optoacoustic imaging in $\operatorname{arcA} \beta$ mouse model of Alzheimer's disease," in Proceedings of the Conference on Photons Plus Ultrasound: Imaging and Sensing 2018, Vol. 10494 (San Francisco, CA: SPIE BiOS). doi: 10.1117/12.2286309

Nitsch, R. M., Kim, C., and Growdon, J. H. (1998). Vasopressin and bradykinin regulate secretory processing of the amyloid protein precursor of Alzheimer's disease. Neurochem. Res. 23, 807-814. doi: 10.1023/A:1022423813362

Noda, M., Kariura, Y., Amano, T., Manago, Y., Nishikawa, K., Aoki, S., et al. (2003). Expression and function of bradykinin receptors in microglia. Life Sci. 72, 1573-1581. doi: 10.1016/S0024-3205(02)02449-9

Nokkari, A., Abou-El-Hassan, H., Mechref, Y., Mondello, S., Kindy, M. S., Jaffa, A. A., et al. (2018). Implication of the Kallikrein-Kinin system in neurological disorders: quest for potential biomarkers and mechanisms. Prog. Neurobiol. 16, 26-50. doi: 10.1016/j.pneurobio.2018.01.003

Passos, G. F., Medeiros, R., Cheng, D., Vasilevko, V., Laferla, F. M., and Cribbs, D. H. (2013). The bradykinin B1 receptor regulates Abeta deposition and neuroinflammation in Tg-SwDI mice. Am. J. Pathol. 182, 1740-1749. doi: 10.1016/j.ajpath.2013.01.021
Paxinos, G., and Franklin, K. (2012). Paxinos and Franklin's the Mouse Brain in Stereotaxic Coordinates, 4th Edn. Cambridge, MA: Academic Press.

Prediger, R. D., Medeiros, R., Pandolfo, P., Duarte, F. S., Passos, G. F., Pesquero, J. B., et al. (2008). Genetic deletion or antagonism of kinin $B(1)$ and $B(2)$ receptors improves cognitive deficits in a mouse model of Alzheimer's disease. Neuroscience 151, 631-643. doi: 10.1016/j.neuroscience.2007.11.009

Princz-Kranz, F. L., Mueggler, T., Knobloch, M., Nitsch, R. M., and Rudin, M. (2010). Vascular response to acetazolamide decreases as a function of age in the arcA beta mouse model of cerebral amyloidosis. Neurobiol. Dis. 40, 284-292. doi: 10.1016/j.nbd.2010.06.002

Rodriguez-Vieitez, E., Ni, R., Gulyas, B., Toth, M., Haggkvist, J., Halldin, C., et al. (2015). Astrocytosis precedes amyloid plaque deposition in Alzheimer APPswe transgenic mouse brain: a correlative positron emission tomography and in vitro imaging study. Eur. J. Nuclic Med. Mol. Imaging 42, 1119-1132. doi: 10.1007/s00259-015-3047-0

Schmaier, A. H. (2016). Alzheimer disease is in part a thrombohemorrhagic disorder. J. Thromb. Haemost. 14, 991-994. doi: 10.1111/jth.13277

Spani, C., Suter, T., Derungs, R., Ferretti, M. T., Welt, T., Wirth, F., et al. (2015). Reduced beta-amyloid pathology in an APP transgenic mouse model of Alzheimer's disease lacking functional B and T cells. Acta Neuropathol. Commun. 3:71. doi: 10.1186/s40478-015-0251-x

Stoppe, G., Schutze, R., Kogler, A., Staedt, J., Munz, D. L., Emrich, D., et al. (1995). Cerebrovascular reactivity to acetazolamide in (senile) dementia of Alzheimer's type: relationship to disease severity. Dementia 6, 73-82.

Tsunoda, N., and Yoshimura, H. (1979). Metabolic fate of noscapine. II. Isolation and identification of novel metabolites produced by C-C bond cleavage. Xenobiotica 9, 181-187. doi: 10.3109/00498257909038719

Viel, T., and Buck, H. (2011). Kallikrein-kinin system mediated inflammation in Alzheimer's disease in vivo. Curr. Alzheimer Res. 8, 59-66. doi: 10.2174/ 156720511794604570

Viel, T. A., Lima Caetano, A., Nasello, A. G., Lancelotti, C. L., Nunes, V. A., Araujo, M. S., et al. (2008). Increases of kinin B1 and B2 receptors binding sites after brain infusion of amyloid-beta 1-40 peptide in rats. Neurobiol. Aging 29, 1805-1814. doi: 10.1016/j.neurobiolaging.2007.04.019

Vorstrup, S., Henriksen, L., and Paulson, O. (1984). Effect of acetazolamide on cerebral blood flow and cerebral metabolic rate for oxygen. J. Clin. Invest. 74, 1634-1639. doi: 10.1172/JCI111579

Zerbi, V., Jansen, D., Wiesmann, M., Fang, X., Broersen, L. M., Veltien, A., et al. (2014). Multinutrient diets improve cerebral perfusion and neuroprotection in a murine model of Alzheimer's disease. Neurobiol. Aging 35, 600-613. doi: 10.1016/j.neurobiolaging.2013.09.038

Zhang, X., Petersen, E. T., Ghariq, E., De Vis, J. B., Webb, A. G., Teeuwisse, W. M., et al. (2013). In vivo blood $\mathrm{T}(1)$ measurements at $1.5 \mathrm{~T}$, 3 T, and 7 T. Magn. Reson. Med. 70, 1082-1086. doi: 10.1002/mrm. 24550

Conflict of Interest Statement: The authors declare that the research was conducted in the absence of any commercial or financial relationships that could be construed as a potential conflict of interest.

Copyright () 2019 Ni, Kindler, Waag, Rouault, Ravikumar, Nitsch, Rudin, Camici, Liberale, Kulic and Klohs. This is an open-access article distributed under the terms of the Creative Commons Attribution License (CC BY). The use, distribution or reproduction in other forums is permitted, provided the original author(s) and the copyright owner(s) are credited and that the original publication in this journal is cited, in accordance with accepted academic practice. No use, distribution or reproduction is permitted which does not comply with these terms. 